\title{
Development of a global model of mineral dust aerosol microphysics
}

\author{
Y. H. Lee ${ }^{1}$, K. Chen ${ }^{2}$, and P. J. Adams ${ }^{1,3}$ \\ ${ }^{1}$ Department of Civil and Environmental Engineering, Carnegie Mellon University, Pittsburgh, PA, USA \\ ${ }^{2}$ Vermilion Asset Management, New York, NY, USA \\ ${ }^{3}$ Department of Engineering and Public Policy, Carnegie Mellon University, Pittsburgh, PA, USA
}

Received: 29 July 2008 - Published in Atmos. Chem. Phys. Discuss.: 31 October 2008

Revised: 18 February 2009 - Accepted: 20 March 2009 - Published: 3 April 2009

\begin{abstract}
A mineral dust module is developed and implemented into the global aerosol microphysics model, GISSTOMAS. The model is evaluated against long-term measurements of dust surface mass concentrations and deposition fluxes. Predicted mass concentrations and deposition fluxes are in error on average by a factor of 3 and 5, respectively. The comparison shows that the model performs better near the dust source regions but underestimates surface concentrations and deposition fluxes in more remote regions. Including only sites with measured dust concentrations of at least $0.5 \mu \mathrm{g} \mathrm{m}^{-3}$, the model prediction agrees with observations to within a factor of 2 . It was hypothesized that the lifetime of dust, 2.6 days in our base case, is too short and causes the underestimation in remote areas. However, a sensitivity simulation with smaller dust particles and increased lifetime, 3.7 days, does not significantly improve the comparison. These results suggest that the underestimation of mineral dust in remote areas may result from local factors/sources not well described by the global dust source function used here or the GCM meteorology. The effect of dust aerosols on $\mathrm{CCN}(0.2 \%)$ concentrations is negligible in most regions of the globe; however, $\mathrm{CCN}(0.2 \%)$ concentrations change decrease by $10-20 \%$ in dusty regions the impact of dust on $\mathrm{CCN}(0.2 \%)$ concentrations in dusty regions is very sensitive to the assumed size distribution of emissions. If emissions are predominantly in the coarse mode, $\mathrm{CCN}(0.2 \%)$ decreases in dusty regions up to $10-20 \%$ because dust competes for condensable $\mathrm{H}_{2} \mathrm{SO}_{4}$, reducing the condensational growth of ultrafine mode particles to $\mathrm{CCN}$ sizes. With significant fine mode emissions, however, $\mathrm{CCN}(0.2 \%)$ doubles
\end{abstract}

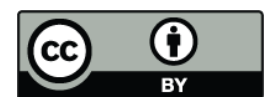

Correspondence to: $\mathrm{Y}$. H. Lee (yunhal@andrew.cmu.edu) in Saharan source regions because the direct emission of dust particles outweighs any microphysical feedbacks. The impact of dust on $\mathrm{CCN}$ concentrations active at various water supersaturations is also investigated. Below $0.1 \%, \mathrm{CCN}$ concentrations increase significantly in dusty regions due to the presence of coarse dust particles. Above $0.2 \%, \mathrm{CCN}$ concentrations show a similar behavior as $\mathrm{CCN}(0.2 \%)$.

\section{Introduction}

Atmospheric aerosols are important contributors to global climate change. They perturb the Earth's energy balance by scattering or absorbing solar and terrestrial radiation, which are known as "direct effects" of aerosols. Also, they change cloud properties by increasing their albedo (reflectance) and may increase their lifetime, which are termed "indirect effects". Aerosol effects on the global climate system are generally thought to be a net negative (cooling) radiative forcing, which partly compensates for the positive radiative forcing of greenhouse gases such as carbon dioxide. According to a recent report from the Intergovernmental Panel on Climate Change (IPCC), the global and annual average radiative forcings from direct and indirect effects are estimated to be $-0.5 \mathrm{Wm}^{-2}\left( \pm 0.4 \mathrm{Wm}^{-2}\right.$ for the $90 \%$ confidence interval) and $-0.7 \mathrm{Wm}^{-2}$ ( -1.8 to $-0.3 \mathrm{Wm}^{-2}$ for the $90 \%$ confidence interval), respectively. Estimates of direct and indirect effects, however, include a large uncertainty due to poor understanding of aerosol properties and behaviors including aerosol physical, chemical, and optical properties, and microphysical processes affecting size distributions.

Mineral dust aerosol mobilized by wind erosion in arid and semi-arid areas contributes to the global aerosol burden

Published by Copernicus Publications on behalf of the European Geosciences Union. 
significantly. Interest in mineral dust has increased significantly due to its many important roles in the Earth's climate system. Dust aerosol modifies the radiation budget in the atmosphere through by direct effects (Tegen and Lacis, 1996; Haywood and Boucher, 2000; Sokolik et al., 2001; Prospero et al., 2002; Chin et al., 2002). The direct radiative forcing by anthropogenic mineral dust is $-0.1 \mathrm{Wm}^{-2}$ $\left( \pm 0.2 \mathrm{Wm}^{-2}\right)$ as estimated in the IPCC Fourth Assessment Report; dust aerosol can have either a net positive or negative forcing depending on its single scattering albedo and the underlying surface albedo (Liao and Seinfeld, 1998). Mineral dust aerosols may influence climate indirectly through interaction with liquid clouds or acting as ice nuclei and modifying cloud properties and precipitation processes (Levin and Ganor, 1996; Rosenfeld et al., 2001; Sassen et al., 2003; Mahowald and Kiehl, 2003). In the presence of mineral dust, gas phase chemistry can be altered either by serving as a reaction surface or reacting with gas species (e.g. Dentener et al., 1996; Umann et al., 2005). Dust particles ranging from 0.1 to $10 \mu \mathrm{m}$ in diameter tend to undergo long range transport and are deposited in remote areas, causing both positive and negative effects on terrestrial and oceanic ecosystems. Dust deposition can provide nutrients to oceans, including iron, which is often a limiting factor for plankton growth (Falkowski et al., 1998; Jickells et al., 2005; Mahowald et al., 2005; Meskhidze et al., 2007). Dust deposition can lead to adverse effects on oceanic ecosystems such as the decline of coral reefs due to dust-borne microorganisms (Shinn et al., 2000; Griffin et al., 2002, 2006). Finally, studies have shown the impact of climate change on dust emissions (e.g. Mahowald et al., 1999; Mahowald and Luo, 2003).

To understand these impacts of mineral dust, its global distribution must be understood and modeled. Even though dust concentrations at the surface have been monitored over several decades, measurements have limited coverage. Satellite measurements complement ground-based observations by providing more complete spatial coverage, but challenges are associated with uncertainties and difficulties in the retrieval processes. A well evaluated dust model can compensate for some of these weaknesses by predicting dust concentrations and characteristics not well observed by these data sets and examining impacts and processes not readily amenable to observations.

The purpose of this work is to develop a dust module to be incorporated into a global aerosol microphysics model and to evaluate it against available observations. The TwO-Moment Aerosol Sectional (TOMAS) microphysics model has been incorporated previously into the Goddard Institute for Space Studies General Circulation Model II-prime (GISS GCM IIprime) and has been developed to study tropospheric aerosol microphysics and predict cloud condensation nuclei (CCN) concentrations. Previously, sulfate, sea-salt, and carbonaceous aerosol modules have been developed in the TOMAS framework (Adams and Seinfeld, 2002; Pierce and Adams, 2006; Pierce et al., 2007). With the addition of mineral dust in this work, the TOMAS model includes all the major climatically significant aerosol types. In this work, we use previously existing dust source functions to simulate mineral dust in the TOMAS framework, thereby completing development of the GISS-TOMAS model and studying the impacts of mineral dust on the tropospheric CCN cycle. The dust module developed in the TOMAS global microphysics model is evaluated against dust surface mass concentrations, deposition flux data, and mass size distributions. Evaluation of model predictions against aerosol optical depth (AOD) measurements will be reported in a separate manuscript.

Section 2 provides general information about the GISS GCM II-prime and TOMAS before documenting the mineral dust module itself. Section 3 presents the simulated dust global budgets and the evaluation of the dust model with observations of dust surface concentrations, deposition, and mass size distributions. The effect of dust aerosols on CCN concentrations is also in this section. Finally, Sect. 4 presents discussion and conclusions for this work.

\section{Model description}

\subsection{General description of GISS GCM and TOMAS}

In this work, we use the GISS GCM II-prime as the host model for the TOMAS aerosol microphysics simulation; the GISS-TOMAS model refers to the GISS GCM II-prime and the TOMAS aerosol model. The GISS GCM provides meteorological data required by TOMAS. In this model, equations for conservation of energy, mass, momentum, and the equation of state are combined and solved for each grid cell. The GISS GCM has horizontal grid dimensions of $4^{\circ}$ latitude by $5^{\circ}$ longitude, with nine vertical sigma layers predominantly in the troposphere but including the stratosphere to the $10 \mathrm{hPa}$ level (Hansen et al., 1983). The GISS GCM II is described in detail in Hansen et al. (1983), and the model has been updated (to the II-prime version) by Del Genio and Yao (1993), Del Genio et al. (1996), Hartke and Rind (1997), and Rosenzweig and Abramopoulos (1997). The dynamical time step in the model is 1 hour. The model uses a fourth-order scheme for momentum advection. Chemical tracers, heat, and moisture are advected every hour by the model winds using a quadratic upstream scheme (Prather, 1986).

The TOMAS aerosol microphysics model has been incorporated previously into the GISS GCM and uses a moving sectional approach in which the boundaries between size bins are defined in terms of dry aerosol mass (Adams and Seinfeld, 2002). It tracks two moments of the aerosol size distribution in each size bin, total aerosol number and mass concentrations for each aerosol species, explicitly simulating the microphysical processes of nucleation, condensation, and coagulation to predict the aerosol size distribution. The model has 30 size bins with the lower boundary of the smallest size bin being $10^{-21} \mathrm{~kg}$ dry mass, and each successive boundary 
has twice the mass of the previous boundary. The size distribution ranges from $10 \mathrm{~nm}$ to $10 \mu \mathrm{m}$ dry diameter for typical aerosol densities. A detailed description of the TOMAS model is in Adams and Seinfeld (2002).

Sulfate (Adams and Seinfeld, 2002), sea-salt (Pierce and Adams, 2006), and carbonaceous aerosols (Pierce et al., 2007) have been developed previously for the GISS-TOMAS model and are incorporated here as well. The sulfur model uses the GEIA emissions inventory (Benkovitz, et al., 1996). Three percent of total anthropogenic sulfur is emitted as particulate sulfate (Adams and Seinfeld, 2002). Sea-salt emission is based on Clarke et al. (2006), and anthropogenic carbonaceous aerosol emissions are from Bond et al. (2004).

Atmospheric wet deposition, in general, has three scavenging mechanisms: nucleation/activation scavenging, interstitial scavenging, and below-cloud scavenging. In this model, interstitial scavenging of non-activated particles in clouds is ignored. The GISS GCM distinguishes between large-scale (stratiform) and convective clouds as described by Del Genio and Yao (1993) and Del Genio et al. (1996). Nucleation/activation scavenging occurs in large-scale and convective clouds, which are assumed to have supersaturations of $0.2 \%$ and $1.0 \%$, respectively. To determine which size sections activate, modified Köhler theory is used to obtain the critical supersaturations for activation that are evaluated at the boundaries of each size section given the composition of particles in that size section (Pierce et al., 2007). When the cloud supersaturation exceeds (does not exceed) the critical supersaturation at the lower (upper) size boundary, all of the particles are assumed to activate (remain as interstitial aerosol). When the critical supersaturation is intermediate between that required at the size bin boundaries, linear interpolation within the activating size bin is used to determine the fraction of particles activated. Activated particles follow the GCM cloud water such that the fraction of activated particles removed by wet deposition is proportional to the fraction of cloud water that precipitates. Belowcloud scavenging uses a first-order removal scheme first implemented for bulk aerosols by Koch et al. (1999), and in TOMAS, that method is adapted for size-resolved aerosols (Adams and Seinfeld, 2002).

Dry deposition is based on the series resistance approach with size-dependent gravitational settling of particles and a size-dependent resistance in the quasi-laminar sublayer (Seinfeld and Pandis, 1998; Adams and Seinfeld, 2002). Aerodynamic resistances are calculated as a function of GCM surface momentum and heat fluxes. The surface resistance is assumed to be negligible for aerosol species.

\subsection{Dust model description}

A dust aerosol module is developed for the TOMAS model and runs in conjunction with the previously existing sizeresolved sulfur, sea-salt, and carbonaceous aerosols mod- ules. Dust emission is based on Ginoux et al. (2004) and explained in detail in the next sub-section. For purposes of activation and nucleation scavenging calculations, mineral dust is treated as insoluble, but dust is assumed to be internally mixed with other aerosol species, which accounts for aging of dust as sulfate condenses onto it. Other species are treated in activation calculations as described in Pierce et al. (2007). Dust is removed by dry deposition in the first vertical layer using the size-resolved deposition velocities described in Adams and Seinfeld (2002). Dust particles undergo gravitational settling between model vertical layers due to their large size. To improve the simulation of the vertical distribution of coarse mineral dust as well as coarse sea-salt, gravitational settling between vertical layers is newly implemented into the GISS-TOMAS model. It uses the Stokes settling velocity to account for settling of particles from an upper vertical layer to a lower vertical layer. Since the settling velocity is proportional to the square of particle diameter, gravitational settling results in larger changes to the budgets of coarse particles such as dust aerosols than those of fine particles such as sulfate aerosols.

\subsubsection{Dust emissions}

Dust aerosol is mobilized into the atmosphere by a sandblasting process occurring during "saltation", in which the kinetic energy carried by saltating sand particles results in mobilization of smaller particles. This process is still not well understood with many factors potentially playing a role in determining dust emission rates. However, the most important factors are the wind friction velocity, vegetation cover, soil particle size distribution, and soil moisture content. Unfortunately, these factors are not well known on a global scale. Therefore, dust emission parameterizations tend to be semi-empirical expressions derived from experiments and observations (e.g. Gillette and Passi, 1998; Marticorena and Bergametti, 1995). A more physically based model has been proposed by Alfaro and Gomez (2001) that accounts for the sand-blasting process with a parameterization of the size-dependent vertical flux as a function of the horizontal flux (saltation), the soil aggregates size distribution, and wind friction velocity. A difficulty in this approach is that the dust emission vertical flux is a function of the soil aggregates size distribution. Because there is no global database of soil aggregates size distribution, it is generally assumed to be uniform everywhere.

In this work, soil mass fraction is also assumed to be globally constant and is not a function of wind friction velocity. Tegen et al. (2002) estimate that less than $10 \%$ of dust emissions results from human activities, and this work includes dust emissions only from natural processes. The emission parameterization of dust aerosol used here, shown in Eq. (1), is based on Ginoux et al. (2004). That work used an empirical formulation by Gillette and Passi (1998) that shows dust 
emission is proportional to the third power of wind speed above a threshold velocity. The resulting equation is

$$
F_{p}=\left\{\begin{array}{c}
C S s_{k} u_{10}^{2}\left(u_{10}-u_{t}\right): u_{10}>u_{t} \\
0: u_{10} \leq u_{t}
\end{array}\right\}
$$

where $F_{p}$ is the dust mass emission flux $\left(\mu \mathrm{g} \mathrm{m}^{-2} \mathrm{~s}^{-1}\right)$ within a given size section, $C$ is a dimensional factor of $1 \mu \mathrm{g} \mathrm{s}^{2} \mathrm{~m}^{-5}$, $S$ is the source function, $s_{k}$ is the soil fraction that can be uplifted in each size bin, $u_{10}$ is the wind speed at $10 \mathrm{~m}$ altitude, and $u_{t}$ is the threshold velocity for each size bin and has units of $\mathrm{m} \mathrm{s}^{-1}$. Each of these is discussed in more detail in the paragraphs that follow.

The source function, $S$, indicates the probability of having accumulated mobilizable sediment in the grid cell and is calculated using the same method as Ginoux et al. (2001). Previous studies showed that erodible alluvial soils were deposited during earlier pluvial periods in the riverbeds or topographic depression regions corresponding to major dust source areas (e.g. Prospero et al., 2002; Goudie and Middleton, 2001). Ginoux et al. (2001, 2004) use a topographical surface height to specify the source function assuming a basin with pronounced topographic variations contains a large amount of mobile sediment. The source function, $S$, is a function of location, therefore, with high values in all the major dust source areas such as the Sahara and Sahel in Africa, the Taklimakan and Gobi Deserts in China and Mongolia, the Arabian Desert, and the Great Sandy and Great Victorian Deserts in Australia.

The soil fraction, $s_{k}$, gives the fraction of total mass emissions that occurs in each of the 30 size bins of TOMAS. Based on d'Almeida and Schutz (1983), we assume that the mass emissions flux follows the sum of two log-normal distributions that represent silt and clay particles. The silt distribution has a geometric mean number diameter of $1.15 \mu \mathrm{m}$ and a geometric standard deviation of 2 , while the clay distribution has a geometric mean number diameter of $0.14 \mu \mathrm{m}$ and a geometric standard deviation of 2 . Ten percent of the total mass emissions flux results from clay particles (Tegen and Fung, 1994; Prospero and Bonatti, 1969). We assume that $75 \%$ of the mass emissions flux results from particles ranging from $2 \mu \mathrm{m}$ to $10 \mu \mathrm{m}$ in diameter, and the remaining $15 \%$ results from particles larger than $10 \mu \mathrm{m}$ diameter and are not included in this work. The soil fraction for each TOMAS size bin is obtained by integration of these log-normal distributions between the corresponding size bin boundaries.

The threshold wind velocity is mainly determined by the inter-particle adhesive and cohesive forces that are a function of particle size, soil moisture content, and particle density. Small particles, such as clay, have cohesive forces between them that inhibit uplifting, while larger sand particles (greater than $20 \mu \mathrm{m}$ in diameter) have threshold velocities determined primarily by their weight (Tegen and Fung, 1994). The moisture in soil causes an attractive force among soil particles, decreasing the chance to be mobilized into the atmosphere. In this paper, the threshold velocity including soil moisture content, $u_{t}$, is based on the equation given by Ginoux et al. (2001), and the threshold velocity excluding soil moisture content (hereafter it is called dry threshold velocity), $u_{t, 0}$, is based on the parameterization from Marticorena and Bergametti (1995), shown in Eq. (2),

$$
\begin{aligned}
& u_{t}=\left[\begin{array}{ll}
u_{t, 0} \cdot\left(1.2+0.2 \log _{10} w\right) & \text { if } w<0.5 \\
\infty & \text { if } w \geq 0.5
\end{array}\right. \\
& u_{t, 0}=0.0013 \frac{\sqrt{\frac{\rho_{P} g D_{P}}{\rho_{a}}} \sqrt{\left(1+\frac{6 \times 10^{-3}}{\rho_{P} g D_{P}^{2.5}}\right.}}{\sqrt{\left.1.928\left(1331 \times D_{P}^{1.56}+0.38\right)^{0.092}-1\right)}}
\end{aligned}
$$

where $w$ is the soil moisture content; $D_{p}(\mathrm{~cm})$ is a particle diameter; $g\left(=980 \mathrm{~cm} \mathrm{~s}^{-2}\right)$ is gravitational acceleration; $\rho_{a}\left(=0.00125 \mathrm{~g} \mathrm{~cm}^{-3}\right)$ and $\rho_{p}\left(=2.65 \mathrm{~g} \mathrm{~cm}^{-3}\right)$ are air density and particle density, respectively. Along with $s_{k}$, the threshold velocity, $u_{t}$, term determines the dust emission size distribution.

The $u_{10}$ used is a mean wind speed in a grid cell provided by the GISS GCM. There are two challenges associated with using the GISS GCM wind speed. One issue is related to the sub-grid scale variability in wind speed within a grid cell. Dust emission occurs when wind speed is larger than the threshold value; using only a mean wind speed can introduce bias in emission rates. The other issue is that the modeled wind speed is not necessarily representative of the real one, which can also lead modeled dust emissions to be biased. To evaluate emissions biases due to high or low model wind speeds, we calculate a dust "emission ratio" by comparing the GISS GCM wind speed to that from the National Centers for Environmental Prediction (NCEP) reanalysis wind fields for the years 1990-2004. The "emission ratio" is defined in Eq. (3),

Emission $\operatorname{ratio}(\mathrm{i}, \mathrm{j})=\left[\frac{\sum_{\mathrm{t}=0}^{\mathrm{n}}\left(\mathrm{u}_{10, \operatorname{GISS}, \mathrm{t}}(i, j)\right)^{3}}{\sum_{\mathrm{t}=0}^{\mathrm{n}}\left(\mathrm{u}_{10, \operatorname{NCEP}, \mathrm{t}}(\mathrm{i}, \mathrm{j})\right)^{3}}\right]$

where $u_{10, \text { GISS, } t}(i, j)$ is the GISS wind speed at $10 \mathrm{~m}$ in the $i$-th (longitude) and $j$-th (latitude) grid box at time step, $t$; $u_{10, \mathrm{NCEP}, \mathrm{t}}(i, j)$ is the same for the NCEP reanalysis wind speed. Because dust emissions are proportional to wind speed cubed (neglecting any threshold speed), this definition of the emission ratio gives the factor by which emissions are biased high or low due to biases in the GISS wind fields, assuming the NCEP winds are correct. This definition gives a time-averaged wind speed that appropriately weights the high wind speed events that largely determine total emissions; our experience has shown that comparisons based on the usual time-average wind speed (without any exponent) are often misleading in this regard. The functional form of Eq. (3) is approximate because it neglects the threshold velocity, which depends on the time history of soil 
Table 1. Global annual budget of mineral dust aerosol predicted by this model and compared with other models. Note that NR indicates that data are not reported. Also note that $*$ indicates that the model includes dust particles larger than $10 \mu \mathrm{m}$ (the upper size cutoff in this work).

\begin{tabular}{|c|c|c|c|c|c|}
\hline & GISS GCM (Base case) & GISS GCM (Sensitivity) & GOCART* & ECHAM5* & LMD GCM \\
\hline Emission $\left[\operatorname{Tg~yr}^{-1}\right]$ & 2440 & 2030 & 1814 & 662 & 1307 \\
\hline \multicolumn{6}{|l|}{ Percent mass emissions flux } \\
\hline with $\mathrm{D}_{p}<2 \mu \mathrm{m}$ & 5.8 & 14.5 & 18.5 & NR & NR \\
\hline with $\mathrm{D}_{p}<1 \mu \mathrm{m}$ & 0.6 & 4.1 & NR & 1.4 & 9.3 \\
\hline Burden $[\mathrm{Tg}]$ & 17.6 & 20.6 & 35.9 & 8.3 & 12.1 \\
\hline Total lifetime [day] & 2.6 & 3.7 & 7.1 & 4.6 & 3.4 \\
\hline Dry deposition $\left[\mathrm{Tg} \mathrm{yr}^{-1}\right]$ & 1880 & 1370 & 1606 & NR & 924 \\
\hline Dry deposition lifetime [day] & 3.4 & 5.5 & 7.1 & NR & 4.8 \\
\hline Wet deposition $\left[\mathrm{Tg} \mathrm{yr}^{-1}\right]$ & 560 & 659 & 235 & NR & 383 \\
\hline Wet deposition lifetime [day] & 11.5 & 11.4 & 57.1 & NR & 11.5 \\
\hline
\end{tabular}
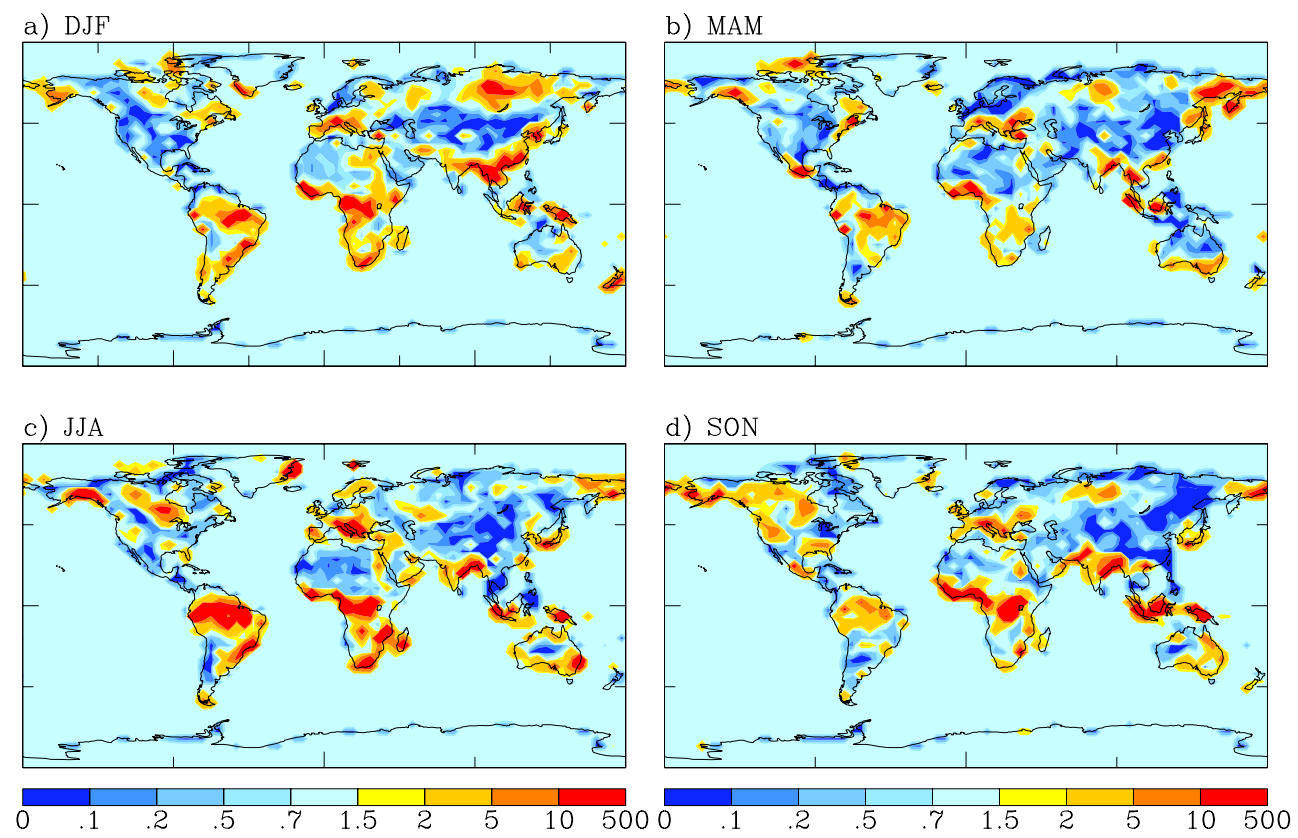

Fig. 1. Seasonally averaged dust "emission ratios" based on a comparison of wind fields in the GISS model with those from the NCEP reanalysis. See text for a full definition and discussion of the "emission ratio". (a) December-February (DJF), (b) March-May (MAM), (c) June-August (JJA), and (d) September-November (SON).

moisture. Figure 1 shows the dust emission ratios thus calculated. The most important features are an underestimation of dust emission in the Sahara during summer and in Taklimakan throughout the year. Cakmur et al. (2004) and Miller et al. (2006), dust models that run in the GISS GCM ModelE, report significant underestimations of dust in Sahara especially during summer and in Taklimakan throughout the year as well. Although they used a different version of the GISS GCM, similar wind speed biases in their version may cause biased dust emissions over these locations.

\section{Model results}

In this section, the globally averaged budget of dust aerosol is presented and model predictions are evaluated against the surface dust mass concentrations and the total dust deposition flux. The model results presented here are based on a one-year simulation with an initial three months discarded for model spinup purposes. The GISS GCM provides a climatological meteorology; therefore, a model year does not correspond to an actual year. Thus, multi-year observations are used to evaluate the model predictions in order to take interannual variation of the observations into account. 


\subsection{Global dust budgets}

Table 1 presents the annual budget of dust aerosols simulated by the GISS GCM and compared with previous work. Dust aerosol budget data from the GOCART, ECHAM5, and LMD GCM models are obtained from Ginoux et al. (2001), Stier et al. (2005), and Reddy et al. (2005), respectively. Note that emission and burden data from GOCART and ECHAM5 model cannot be compared exactly with our model budget because these models include dust particles larger than $10 \mu \mathrm{m}$. Our simulated annual dust emission is $2440 \mathrm{Tg} \mathrm{yr}^{-1}$, which is slightly higher than the other models shown in Table 1 and an estimated range of 1000 to $2150 \mathrm{Tg} \mathrm{yr}^{-1}$ (Zender et al., 2004). The predicted annual burden of dust is $17.6 \mathrm{Tg}$ with an lifetime of 2.6 days. The burden is within the range of other models presented in Table 1 and the range of 8 to $36 \mathrm{Tg}$ presented in Zender et al. (2004). Although our predicted dust emission is higher, the burden is intermediate due to the short dust lifetime, shortest of the models listed in Table 1. A short lifetime can result from emissions of predominantly larger particles with higher dry deposition velocities, or more frequent scavenging. However, the following evidence suggests that the emissions size distribution is playing some role in the model's short lifetime compared to other global models. The percent mass emissions flux of clay particles $\left(\mathrm{D}_{p}<2 \mu \mathrm{m}\right)$ for our model is $5.8 \%$, while that in GOCART by Ginoux et al. (2001) is $18.5 \%$. Particles smaller than $1 \mu \mathrm{m}$ represent only $0.6 \%$ of our total mass emissions, but the corresponding values in ECHAM5 by Stier et al. (2005), which is based on AEROCOM emissions, and LMD-GCM by Reddy et al. (2005) are $1.4 \%$ and $9.3 \%$, respectively. The percent mass emissions flux of fine particles is less than half that found in other models, and this could be due to our parameterization of the dry threshold velocity, $u_{t, 0}$, based on Marticorena and Bergametti (1995). This parameterization requires higher threshold velocities for smaller particles; therefore, the model tends to emit relatively more coarse dust particles, which would then lead to a short lifetime. Dry deposition contributes $77 \%$ of the total removal rate, or $1880 \mathrm{Tg} \mathrm{yr}^{-1}$. The lifetime with respect to dry deposition, 3.4 days, is slightly shorter than that in the other three global models listed in Table 1, consistent with the relatively larger sizes of dust particles in this model. In a sensitivity simulation that uses the dry threshold velocity based on Ginoux et al. (2001) (see Sect. 3.5), the percent mass emissions flux of clay particles is increased to $14.5 \%$. The total lifetime of mineral dust is increased to 3.7 days.

Table 2 shows size-resolved annual budgets of mineral dust mass in the base and sensitivity cases. The sensitivity case shows that the emissions and burdens of fine dust particles, $\mathrm{D}_{p}<2.0 \mu \mathrm{m}$, approximately double, while those of coarse particles (greater than $2.0 \mu \mathrm{m}$ ) are reduced by $24 \%$ and $9 \%$, respectively. As one would expect, the deposition lifetimes of each size category are similar between both the base case and sensitivity simulations, illustrating the dom-

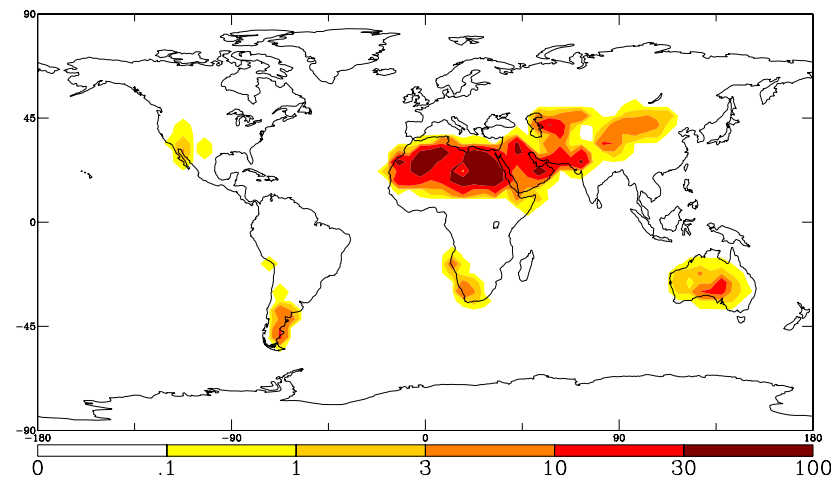

Fig. 2. Global distribution of the predicted annual dust mass emissions flux $\left[\mathrm{g} \mathrm{m}^{-2} \mathrm{yr}^{-1}\right]$.

inant effect of particle size in determining lifetime. The dry deposition lifetime for coarse $\left(\mathrm{D}_{p}>2.0 \mu \mathrm{m}\right)$ particles is somewhat longer in the sensitivity case, reflecting the shift in the size distribution to smaller sizes within this size category. Otherwise, the dry and wet deposition lifetimes within a given size category are very similar. Therefore, the longer lifetime of dust overall in the sensitivity case is primarily the result of a shift in the dust mass size distribution to longerlived smaller particles. Although the mass budgets presented here are similar between the base and sensitivity cases, the number of dust particles in the sensitivity case is substantially higher, which is important for the impact of mineral dust on CCN.

The global distribution of annual-average dust emission flux is presented in Fig. 2. There are major dust source regions shown in the figure such as the Saharan and Sahel regions in North Africa, the Kalahari and Namib deserts in South Africa, the Arabian desert, the Taklimakan and Gobi deserts in Asia, the Australian deserts, the Patagonian desert in South America, and the Southwest of North America. Throughout the year, the largest amount of dust aerosols emitted is in North Africa and Asia, while the dust emitted from South Africa, South America, and North America are not significant on a global scale. However, they can be regionally important because of links to local air quality and transport of dust aerosols to nearby receptor regions as well as long distance regions, e.g. the transport of dust emitted from Patagonia into the Southern Ocean (Gassó and Stein, 2007).

\subsection{Dust surface mass concentrations}

The global distribution of mineral dust mass concentrations in the model surface layer is presented for the four seasons in Fig. 3. Two large source regions, North Africa and Asia, contribute to the broad transport of mineral dust throughout the Northern Hemisphere (NH). The Sahara/Sahel source region has a maximum concentration during MAM and a minimum during SON. During JJA, concentrations in the western part 
Table 2. Size-resolved global aerosol budgets of mineral dust in the base case and sensitivity case.

\begin{tabular}{llcccc}
\hline & D $p$ range $[\mu \mathrm{m}]$ & below 0.2 & $0.2-1.0$ & $1.0-2.0$ & $2.0-10.0$ \\
\hline \multirow{2}{*}{ Base case } & Emission [Tg/yr] & N/A & 14.0 & 128 & 2300 \\
& Burden [Tg] & N/A & 0.38 & 3.3 & 14 \\
& Dry deposition [Tg/yr] & N/A & 0.70 & 18.3 & 1860 \\
& Wet deposition [Tg/yr] & N/A & 13.1 & 109 & 436 \\
& Total deposition lifetime [days] & N/A & 10.0 & 9.4 & 2.2 \\
& Dry deposition lifetime [days] & N/A & 199 & 63.9 & 2.7 \\
& Wet deposition lifetime [days] & N/A & 10.7 & 10.3 & 11.7 \\
\hline \multirow{2}{*}{ Sensitivity case } & Emission [Tg/yr] & 2.67 & 80.8 & 211 & 1740 \\
& Burden [Tg] & 0.045 & 2.3 & 5.5 & 12.7 \\
& Dry deposition [Tg/yr] & 0.11 & 3.7 & 28.4 & 1340 \\
& Wet deposition [Tg/yr] & 1.47 & 76.0 & 182 & 400 \\
& Total deposition lifetime [days] & 10.4 & 10.3 & 9.6 & 2.7 \\
& Dry deposition lifetime [days] & 145 & 227 & 68.0 & 3.5 \\
& Wet deposition lifetime [days] & 11.3 & 11.0 & 9.8 & 11.6 \\
\hline
\end{tabular}

\section{a) DJF}

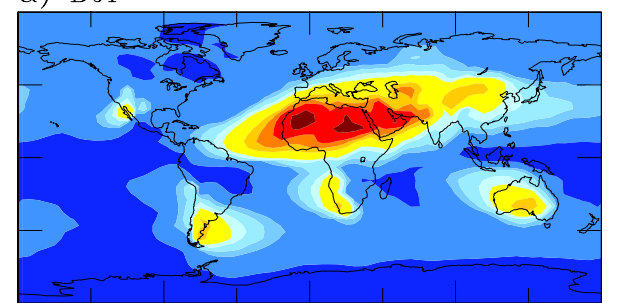

c) JJA
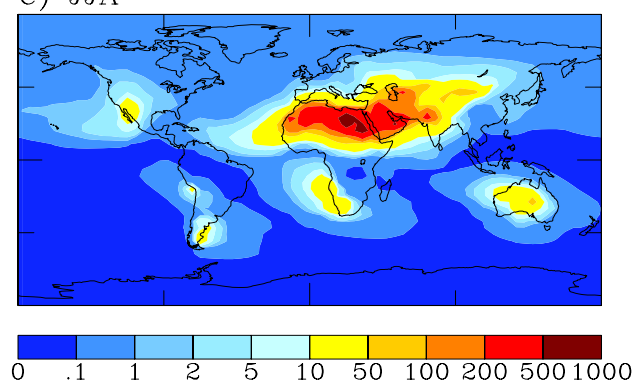

\section{b) MAM}

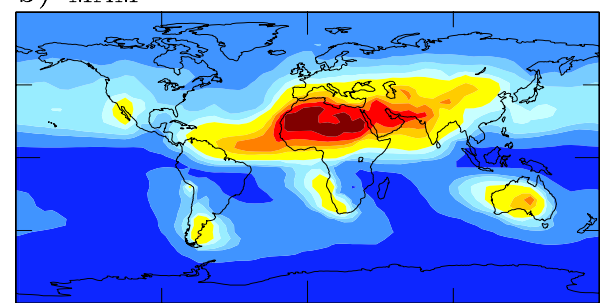

d) $\mathrm{SON}$

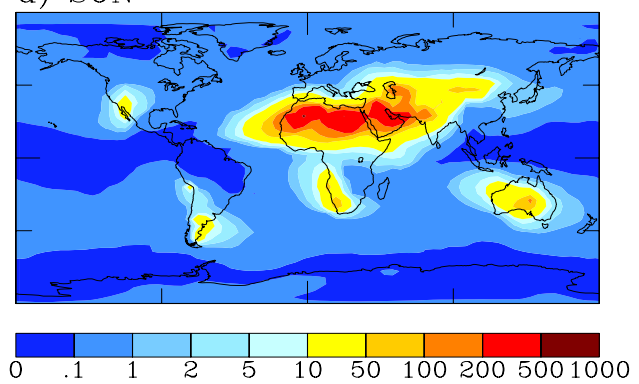

e) Observation sites

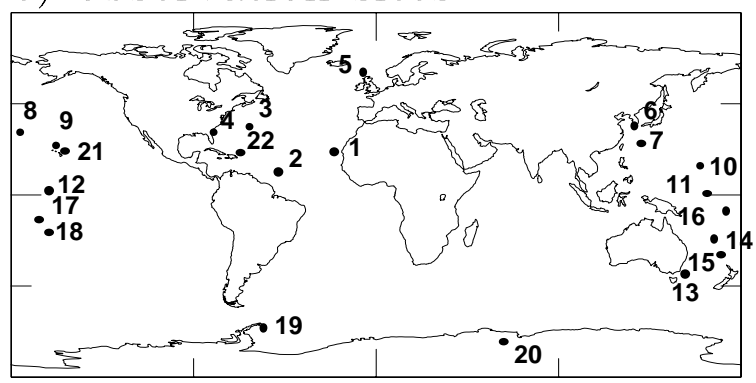

Fig. 3. Global distributions of the dust mass concentrations, $\left[\mu \mathrm{g} \mathrm{m}^{-3}\right.$ at $273 \mathrm{~K}$ and $1013 \mathrm{hPa}$ ] in the model surface layer for (a) DecemberFebruary (DJF), (b) March-May (MAM), (c) June-August (JJA), and (d) September-November (SON), (e) the geographical location of observation sites. Note the number given at each site corresponds to the site number in Table 3 . 


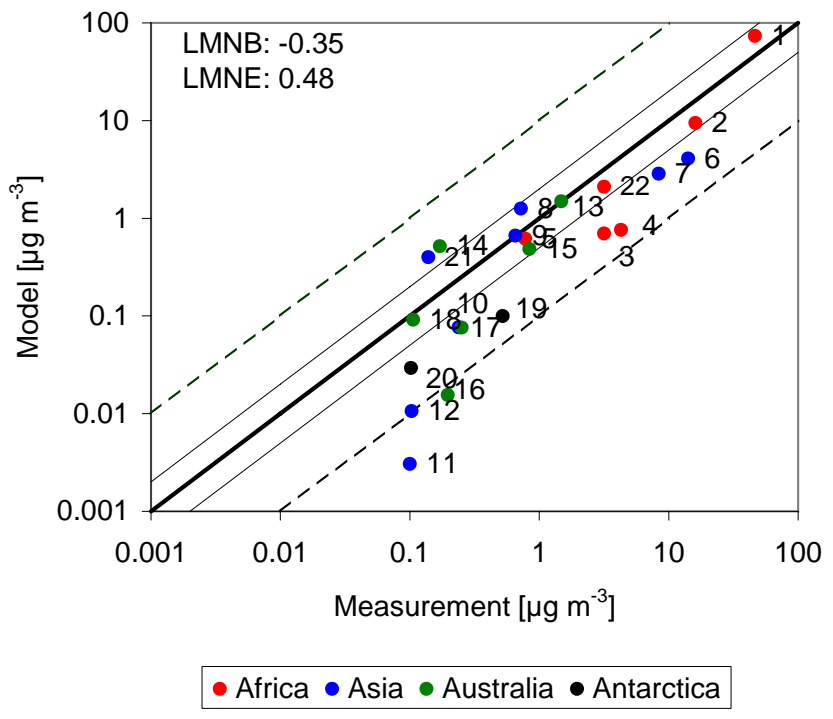

Fig. 4. Scatter plot of annually averaged surface mass concentrations of mineral dust predicted by the model and measurements in units of $\mu \mathrm{g} \mathrm{m}^{-3}$ at $273 \mathrm{~K}$ and $1013 \mathrm{hPa}$. Log-mean normalized bias (LMNB) and log-mean normalized error (LMNE) are given. Thick and thin solid lines are the 1:1 line and 2:1 lines, respectively. Dashed lines are 10:1 lines. Note the number given at each site corresponds to the site number in Table 3.

of the Sahara are noticeably suppressed. According to observations, however, North African dust is emitted throughout the year and especially during summer, when the high dust emissions are related to the strong convective disturbances that occur over West Africa (Goudie and Middleton, 2001; Prospero et al., 1989; Prospero, 1996). Emission rates of mineral dust in the model are low during JJA, and this is most likely due to the underestimation of surface wind speeds in West Africa during that time period (see Fig. 1 and Sect. 2.2.1). Dust is widely distributed in the Southern Hemisphere (SH) during SON and DJF. Mineral dust in the $\mathrm{SH}$ is transported to oceans near the source regions, albeit on a more limited scale. Figure $3 e$ shows geographical locations of 20 sites with long-term measurements of dust mass concentrations made by researchers from the University of Miami (Savoie and Prospero, 1989; Prospero et al., 1989) and 2 sites with long-term measurements of fine mode dust mass concentration from the Interagency Monitoring of Protected Visual Environments (IMPROVE) network. Site information and corresponding measurement time periods are listed in Table 3. For convenience, all sites are categorized into four regions: Africa, Asia, Australia, and Antarctica. These divisions help diagnose model biases in either emissions or transport.

Figure 4 compares the simulated annual-average dust surface concentration with measurements and gives the logmean normalized bias (LMNB) and log-mean normalized error (LMNE), which are defined as follows:

$$
\begin{aligned}
\mathrm{LMNB} & =\frac{\sum_{i=1}^{N} \log _{10}\left(\frac{C_{\bmod , i}}{C_{\mathrm{obs}, i}}\right)}{N} \\
\mathrm{LMNE} & =\frac{\sum_{i=1}^{N} \mathrm{abs}\left[\log _{10}\left(\frac{\mathrm{C}_{\bmod , \mathrm{i}}}{\mathrm{C}_{\mathrm{obs}, \mathrm{i}}}\right)\right]}{N}
\end{aligned}
$$

where $C_{\mathrm{mod}, i}$ is the model-predicted mass concentration at site $i, C_{\mathrm{obs}, i}$ is the observed mass concentration at site $i$, and $N$ is the total number of observation sites. Only two stations, Sal Island (1) and Cape Grim (2), are located very near source regions; the remaining stations can be regarded as long range transport or remote background. The LMNB of -0.40 indicates an average underestimation by a factor of 2.5. The LMNE is 0.49 , which means that the model predictions are, on average, within a factor of 3.1 of observed values. Overall, the model agrees better with the measurements at higher concentrations. Stations showing highly biased model prediction are located either near the equator or Antarctica. The tendency to underpredict mostly in more remote areas suggests that the model transport and relatively short lifetime may be responsible for the biases. In Sect. 3.5, we investigate this possibility with a sensitivity simulation. Without stations with annual-average concentrations below $0.5 \mu \mathrm{g} \mathrm{m}^{-3}$, LMNB is improved to -0.27 (an underestimate by a factor of 1.84) and LMNE is 0.33 (within a factor of 2.2).

Figure 5 presents temporal distributions of monthly averaged dust mass concentration predictions and observations. Stations numbered 1 to 5 and 22 are influenced by African dust events. Annual-average dust concentrations at Sal Island (1), Barbados (2), Mace Head (5), and Virgin Islands (22) agree with observational data within a factor of two, but at Bermuda (3) and Miami (4) the agreement is only within a factor of 6 as depicted in Fig. 4. Figure 5 shows that the seasonal cycle is predicted well very near source regions $(1,13)$ but not downwind. The maximum dust concentration in the Sal Island observations is during winter (DJF), not during the summer (JJA) when other African sites (2, 3, 4, and 22) measure maximum concentrations. Because dust is transported at high altitude during summer, it does not contribute much to dust concentrations at the surface at Sal Island (e.g. Carlson and Prospero, 1972; Chiapello et al., 1995, 1999). In the model, low wind speeds during JJA, as discussed in Sect. 3.2, cause low dust emissions and low dust concentrations at the downwind sites.

In Fig. 4, Asian dust at downwind sites such as Midway (8) and Oahu (9) show good agreement to within a factor of two, but other locations agree less well. Given that nearsource sites, Jeju Island (6) and Hedo (7) show more disagreement than Midway (8) and Oahu (9), this is somewhat surprising. According to Uematsu et al. (1983) and Arimoto et al. (1996), dust in the upper troposphere is transported 

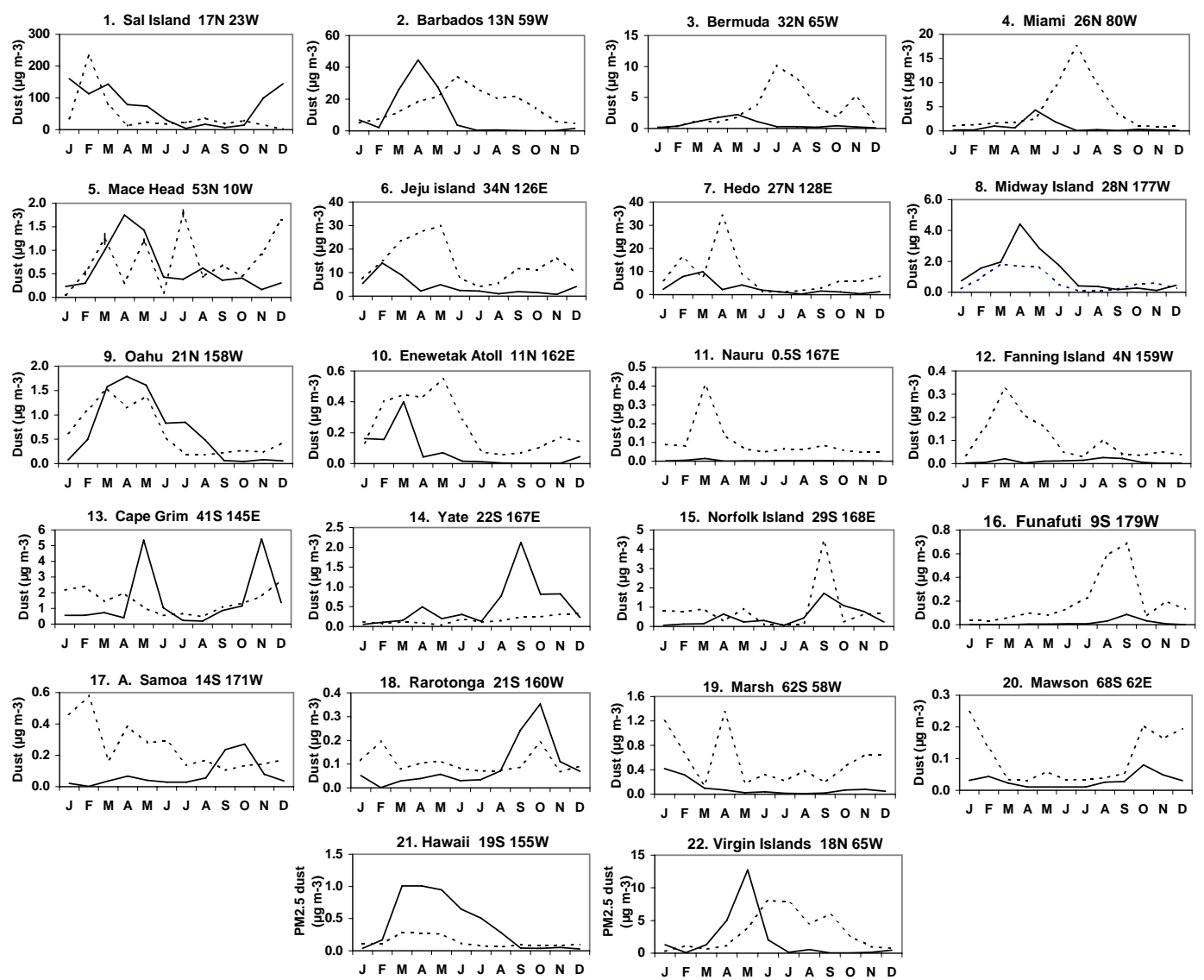

Fig. 5. Comparison of monthly averaged surface dust mass concentrations simulated (solid line) and measured by University of Miami and IMPROVE network (disconnected line) at 22 sites, in units of $\mu \mathrm{g} \mathrm{m}^{-3}$ at $273 \mathrm{~K}$ and $1013 \mathrm{hPa}$. Note the number given at each site corresponds to the site number in Table 3.

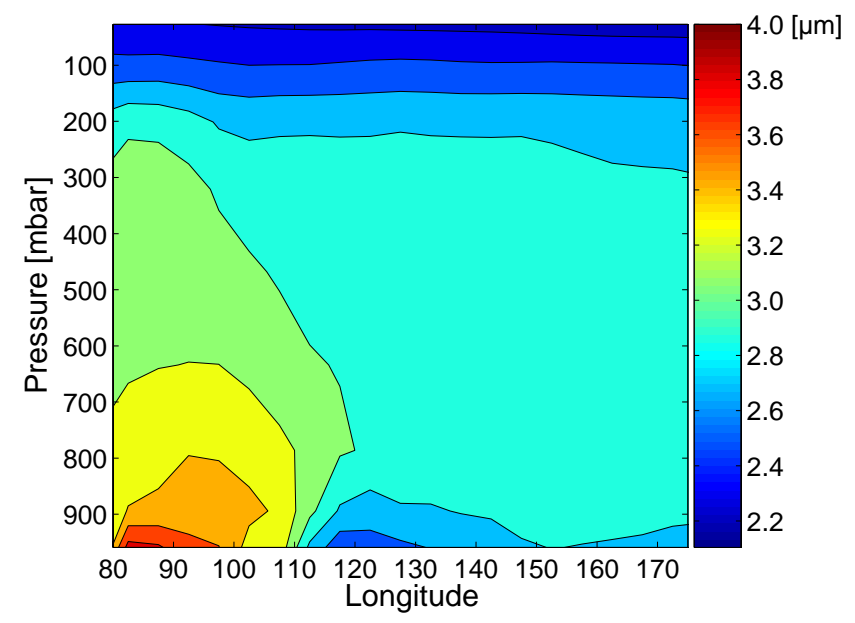

Fig. 6. Annually averaged model prediction of average mineral dust diameter $[\mu \mathrm{m}]$ weighted by dust mass mixing ratio as a function of altitude and longitude. The weighted diameter is averaged between $35^{\circ} \mathrm{N}$ to $45^{\circ} \mathrm{N}$ in latitude. over the Pacific more extensively than that in the lower troposphere; therefore, air carrying dust could pass over Korea and Japan without increasing the surface dust concentration but then subside and result in relatively high dust concentrations in the Northern Pacific area. Figure 6 displays the vertical and longitudinal distribution of predicted average dust particle diameters weighted by mass mixing ratio. The average particle size is also spatially averaged from $30^{\circ} \mathrm{N}$ to $45^{\circ} \mathrm{N}$ latitude to highlight Asian dust. Preferential removal of larger particles results in average dust diameters decreasing as it is transported from the source. Therefore, average dust particle diameter is indicative of the degree of transport. The average diameter in the surface level around $120^{\circ} \mathrm{E}$ to $130^{\circ} \mathrm{E}$ (Korea and Japan) is even smaller than at higher altitudes, which indicates the dust plume is indeed transported to the east mainly at higher altitudes. Low dust concentration in the model at Jeju Island (6) and Hedo (7) might be due to missing particles larger than $10 \mu \mathrm{m}$. In Fig. 4 and 5, Nauru (11) and Fanning Island (12) located near the equator have very poor predictions. The sensitivity simulation in the next section will show that predictions at these sites are not improved by changing dust aerosol lifetime to increase 
Table 3. List of observation sites for surface dust mass concentrations measured by the University of Miami (Sites 1 to 19) and by IMPROVE network (Sites 20 and 21). *Note that the IMPROVE data are for the fine mode $\left(\mathrm{D}_{p}<2.5 \mu \mathrm{m}\right)$ of dust mass concentration.

\begin{tabular}{llrrl}
\hline Site & Location & Latitude & Longitude & Years \\
\hline 1 & Sal Island & $16.8^{\circ} \mathrm{N}$ & $22.9^{\circ} \mathrm{W}$ & $1996-1997$ \\
2 & Barbados & $13.2^{\circ} \mathrm{N}$ & $59.4^{\circ} \mathrm{W}$ & $1984-1998$ \\
3 & Bermuda & $32.3^{\circ} \mathrm{N}$ & $64.9^{\circ} \mathrm{W}$ & $1989-1998$ \\
4 & Univ. of Miami & $25.8^{\circ} \mathrm{N}$ & $80.3^{\circ} \mathrm{W}$ & $1989-1998$ \\
5 & Mace head & $53.3^{\circ} \mathrm{N}$ & $9.9^{\circ} \mathrm{W}$ & $1988-1994$ \\
6 & Jeju Island & $33.5^{\circ} \mathrm{N}$ & $126.5^{\circ} \mathrm{E}$ & $1991-1995$ \\
7 & Hedo & $26.9^{\circ} \mathrm{N}$ & $128.3^{\circ} \mathrm{E}$ & $1991-1994$ \\
8 & Midway Island & $28.2^{\circ} \mathrm{N}$ & $177.4^{\circ} \mathrm{W}$ & $1981-1997$ \\
9 & Oahu, Hawaii & $21.3^{\circ} \mathrm{N}$ & $157.7^{\circ} \mathrm{W}$ & $1981-1995$ \\
10 & Enewetak Atoll & $11.3^{\circ} \mathrm{N}$ & $162.3^{\circ} \mathrm{E}$ & $1981-1987$ \\
11 & Nauru & $0.5^{\circ} \mathrm{S}$ & $167.0^{\circ} \mathrm{E}$ & $1983-1987$ \\
12 & Fanning Island & $3.9^{\circ} \mathrm{N}$ & $159.3^{\circ} \mathrm{W}$ & $1981-1986$ \\
13 & Cape Grim & $40.7^{\circ} \mathrm{S}$ & $144.7^{\circ} \mathrm{E}$ & $1993-1996$ \\
14 & Yate & $22.2^{\circ} \mathrm{S}$ & $167.0^{\circ} \mathrm{E}$ & $1983-1985$ \\
15 & Norfolk Island & $29.1^{\circ} \mathrm{S}$ & $168.0^{\circ} \mathrm{E}$ & $1983-1997$ \\
16 & Funafuti & $8.5^{\circ} \mathrm{S}$ & $179.2^{\circ} \mathrm{E}$ & $1983-1987$ \\
17 & American Samoa & $14.3^{\circ} \mathrm{S}$ & $170.6^{\circ} \mathrm{W}$ & $1983-1999$ \\
18 & Rarotonga & $21.3^{\circ} \mathrm{S}$ & $159.8^{\circ} \mathrm{W}$ & $1983-1994$ \\
19 & Marsh & $62.2^{\circ} \mathrm{S}$ & $58.3^{\circ} \mathrm{W}$ & $1990-1996$ \\
20 & Mawson & $67.60^{\circ} \mathrm{S}$ & $62.50^{\circ} \mathrm{E}$ & $1987-1996$ \\
$21^{*}$ & Hawaii Volcanoes & $19.4^{\circ} \mathrm{N}$ & $155.3^{\circ} \mathrm{W}$ & $1988-1993$ \\
& National Park & & & $2001-2004$ \\
$22 *$ & Virgin Islands & $18.3^{\circ} \mathrm{N}$ & $64.8^{\circ} \mathrm{W}$ & $1991-1998$ \\
\hline
\end{tabular}

long-range transport. In addition, Hawaii (21) shows a slight overestimation of fine mode dust. Perhaps the underestimation at Nauru (11) and Fanning Island (12) is due to a small local dust source that is not well represented by the global emissions parameterization and underestimation of surface wind speed in near the equator (Pierce and Adams, 2006). In addition, using the GISS ModelE, Cakmur et al. (2004) and Miller et al. (2006) also show underprediction of dust near the equator due to heavy precipitation in the model, and a similar problem may be occurring in the GCM II-prime.

Stations from 13 to 18 are influenced by Australian dust. Similar to the previous paragraph, the model predictions are worse near the equator as shown in Fig. 4. Interestingly, the observations show different temporal distributions at many stations, while the model shows a consistent peak during SON and often a smaller peak during MAM. This probably is another indicator that the model does not capture small, highly localized, sources of dust in these locations.

Marsh (19) and Mawson (20) in the Antarctic agree poorly with observations being only within a factor of 6 as depicted in Fig. 4. Antarctic dust measurements presented by Dick (1991) (geographically close to Marsh) show lower concentrations than the model predictions. Due to potential problems of contamination at low concentrations and due to the few observations available in this region, it is not clear whether our model underpredicts dust concentrations in Antarctica. The seasonality of simulated dust concentrations at Marsh is similar to that of South American dust emission; thus, the dust in this region is influenced mostly by South America. The low model values could reflect the underestimation of dust emission in South America.

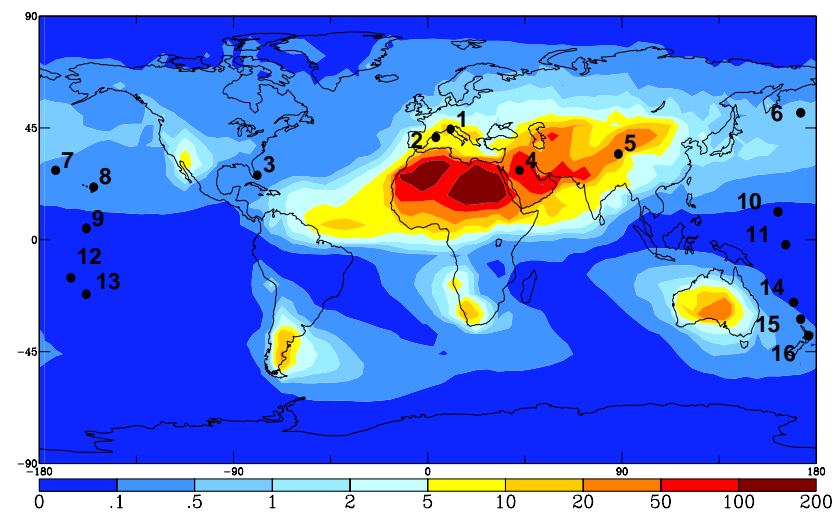

Fig. 7. Global distribution of annually averaged dust mass deposition flux $\left[\mathrm{g} \mathrm{m}^{-2} \mathrm{yr}^{-1}\right]$. Note the number given at each site corresponds to the site number in Table 4. 
Table 4. Lists of measurement sites for total dust deposition fluxes given in Ginoux et al. (2001).

\begin{tabular}{llrrl}
\hline Site & Location & Latitude & Longitude & Years \\
\hline 1 & French Alps & $45.5^{\circ} \mathrm{N}$ & $6.5^{\circ} \mathrm{E}$ & $1955-1985$ \\
2 & Spain & $41.8^{\circ} \mathrm{N}$ & $2.3^{\circ} \mathrm{E}$ & $1987-1990$ \\
3 & Miami & $25.8^{\circ} \mathrm{N}$ & $80.3^{\circ} \mathrm{W}$ & $1982-1983$ \\
4 & Tel Aviv & $32.0^{\circ} \mathrm{N}$ & $34.5^{\circ} \mathrm{E}$ & 1972 \\
5 & Taklimakan & $40.0^{\circ} \mathrm{N}$ & $85.0^{\circ} \mathrm{E}$ & 1994 \\
6 & Shemya & $52.9^{\circ} \mathrm{N}$ & $174.1^{\circ} \mathrm{E}$ & $1981-1987$ \\
7 & Midway & $28.2^{\circ} \mathrm{N}$ & $177.4^{\circ} \mathrm{W}$ & $1981-1987$ \\
8 & Oahu & $21.3^{\circ} \mathrm{N}$ & $157.6^{\circ} \mathrm{W}$ & $1981-1987$ \\
9 & Fanning & $3.9^{\circ} \mathrm{N}$ & $159.3^{\circ} \mathrm{W}$ & $1981-1987$ \\
10 & Enewetak Atoll & $11.3^{\circ} \mathrm{N}$ & $162.3^{\circ} \mathrm{E}$ & $1981-1987$ \\
11 & Nauru & $0.5^{\circ} \mathrm{S}$ & $167.0^{\circ} \mathrm{E}$ & $1981-1987$ \\
12 & Samoa & $14.3^{\circ} \mathrm{S}$ & $170.6^{\circ} \mathrm{W}$ & 1981 \\
13 & Rarotonga & $21.3^{\circ} \mathrm{S}$ & $159.8^{\circ} \mathrm{W}$ & $1981-1987$ \\
14 & Yate & $22.2^{\circ} \mathrm{S}$ & $167.0^{\circ} \mathrm{E}$ & $1983-1985$ \\
15 & Norfolk Island & $29.1^{\circ} \mathrm{S}$ & $167.9^{\circ} \mathrm{E}$ & $1983-1987$ \\
16 & New Zealand & $34.5^{\circ} \mathrm{S}$ & $172.8^{\circ} \mathrm{E}$ & 1983 \\
\hline
\end{tabular}

\subsection{Dust deposition fluxes}

Figure 7 shows a global distribution of annual-average total deposition fluxes in the model. Due to the largest emissions from North Africa, the Atlantic Ocean is significantly influenced by dust aerosols in the model, especially along the primary transport pathway of Saharan dust, usually called the Saharan Air Layer (SAL). In this figure, it is noticeable that the Atlantic Ocean has a local maximum near $10^{\circ}$ to $20^{\circ} \mathrm{N}$ latitude, even though this location is far from the North African deserts. The model deposition flux gives a picture of the amount of dust deposited into the oceans and is important due to the effects of dust deposition on the ocean ecosystem (Griffin et al., 2002, 2006; Jickells et al., 2005).

The measurement site information for total deposition fluxes obtained from Table 6 in Ginoux et al. (2001) are listed in Table 4, the ones obtained from Table 4 in Tegen et al. (2002) are listed in Table 5. It should be noted that some locations have observation periods less than one or two years. To compare the model deposition fluxes against the two observations, two scatter plots of simulated and observed monthly deposition fluxes are presented in Fig. 8. Although the dust deposition measurements are generally at different sites than the mass concentration measurements, the two comparisons show consistent trends. Comparing against the Ginoux et al. (2001) compliation, the simulation of dust deposition flux is underestimated by a factor of 3.7 on average (LMNB: -0.57 ), and the model predictions are typically within a factor of 4.9 of observed values (LMNE: 0.69). The comparison with the Tegen et al. (2002) compliation gives similar results for LMNB $(-0.59)$ and LMNE (0.75). Similar to the comparison of mass concentrations, the model does reasonably well in dusty regions, sometimes with a modest low bias, but underpredicts deposition fluxes more severely in remote regions. In fact, our model may underestimate total deposition flux of dust near source regions because it omits particles larger than $10 \mu \mathrm{m}$ found in those areas. Taklimakan (5) is biased low by a factor of 20 , which could be due to super coarse particles or possible anthropogenic source that is not included in the model. In remote areas, the underprediction of the deposition flux is more severe than for mass concentrations. Either missing large particles (Duce, 1995; personal communication with Cliff Davidson) or missing local emission (Uematsu et al., 1985) might cause the more severe underprediction.

\subsection{Dust size distributions}

Observations of the number size distribution under conditions dominated by mineral dust are obtained from the NASA African Monsoon Multidisciplinary Analysis (NAMMA) campaign and the ACE-Asia campaign. The observed size distribution in the NAMMA campaign (summer 2006) is generated from data collected between 20 and 30 degrees $\mathrm{W}$ longitude and 10 and 20 degrees $\mathrm{N}$ latitude. The observed number size distribution is converted to a mass distribution based on the assumption that dust has a density of $2650 \mathrm{~kg} \mathrm{~m}^{-3}$. The campaign targeted the SAL, so the absolute concentration is expected to be higher than our monthly average grid concentrations. Thus model mass size distributions are scaled to meet the same mass concentration as the measurement with the goal of comparing the shape of the size distribution. The size distribution data measured during local dust storm events in the Chinese deserts is obtained from Zhang et al. (2003), which shows the mean size distributions of dust aerosols from 20 ground-based samples collected at 10-20 m altitude in spring of 1994 and 2001, ACEAsia data plus 6 earlier samples from 1994 (hereafter, referred to simply as ACE-Asia). Their samples are from five locations: Aksu $\left(40.2^{\circ} \mathrm{N}, 80.3^{\circ} \mathrm{E}\right)$, Qira $\left(37.6^{\circ} \mathrm{N}, 82.3^{\circ} \mathrm{E}\right)$, Jarti $\left(40.3^{\circ} \mathrm{N}, 106.3^{\circ} \mathrm{E}\right)$, Dunhuang $\left(40.3^{\circ} \mathrm{N}, 94.5^{\circ} \mathrm{E}\right)$ and Yulin $\left(38.2^{\circ} \mathrm{N}, 109.4^{\circ} \mathrm{E}\right)$. They find a log-normal distribution with aerodynamic mass mean diameter (MMD) of 4.5 and standard deviation $(\sigma)$ of 1.5. We convert the aerodynamic diameter to geometric diameter using a shape factor 1.6, which is used in the NAMMA data, giving a geometric mean diameter of $3.5 \mu \mathrm{m}$. As with NAMMA, model mass size distributions are scaled to meet the same mass concentration. Figure 9 shows the comparison of three mass distributions: observation, base case, and sensitivity simulation (see Sect. 3.5). Model dust mass concentration is sampled during JJA for comparison with the NAMMA measurements. In the ACE-Asia measurements, the measurement height is very close to surface. Therefore, it is reasonable to compare these measurements to the size distribution of dust emissions flux rather than dust mass concentration (Gong et al., 2003), and model dust mass emission size distribution 
Table 5. Lists of measurement sites for total dust deposition fluxes given in Tegen et al. (2002) for the DIRTMAP campaign.

\begin{tabular}{|c|c|c|c|c|}
\hline Sample ID & Location & Category & Latitude & Longitude \\
\hline WS-4 & Weddell sea & Minor source & -64.93 & -2.59 \\
\hline PB2 & Panama Basin & Minor source & 5.37 & -85.58 \\
\hline $\mathrm{P}$ & station papa & Minor source & 50 & -144.98 \\
\hline WR1 & Southern Atlantic & Minor source & -20.07 & 9.17 \\
\hline WR2-LOWER & Southern Atlantic & Minor source & -20.05 & 9.16 \\
\hline WR2-UPPER & Southern Atlantic & Minor source & -20.05 & 9.16 \\
\hline SITE13 shallow & Southern Pacific & Australia & -35.52 & 161 \\
\hline SITE12SHALLOW & Southern Pacific & Australia & -17.76 & 154.83 \\
\hline SITE11SHALLOW & Southern Pacific & Australia & -12.99 & 155.99 \\
\hline CEPS-03 UPPER & Eq. Pacific & Australia & 0 & 175 \\
\hline SITE3 UPPER & Eq. Pacific & Australia & 0 & 175.16 \\
\hline SITE10 & Eq. Pacific & Australia & 1.22 & 160.57 \\
\hline ECC-T & Eq. Pacific & Asia & 5.01 & 138.83 \\
\hline NEC-T & Eq. Pacific & Asia & 12.02 & 134.29 \\
\hline SITE6 & Northern Pacific & Asia & 30 & 175 \\
\hline SITE5UPPER & Northern Pacific & Asia & 34.42 & 177.74 \\
\hline SITE7UPPER & Northern Pacific & Asia & 37.4 & 174.95 \\
\hline WP-3 & Northern Pacific & Asia & 40 & 145.43 \\
\hline SITE8 & Northern Pacific & Asia & 46.12 & 175.03 \\
\hline NP-B & Northern Pacific & Asia & 46.82 & 162.12 \\
\hline M5 & Indian & Middle East & 10 & 65 \\
\hline CAST & Indian & Middle East & 14.48 & 64.77 \\
\hline EAST & Indian & Middle East & 15.47 & 68.75 \\
\hline M4 & Indian & Middle East & 15.98 & 61.5 \\
\hline WAST & Indian & Middle East & 16.25 & 60.47 \\
\hline M2/M3 & Indian & Middle East & 17.4 & 58.8 \\
\hline GBZ4 & Eq. Atlantic & Africa & -2.18 & -9.9 \\
\hline GBN3 UPPER & Eq. Atlantic & Africa & 1.79 & -11.13 \\
\hline CV 1 UPPER & Eq. Atlantic & Africa & 11.48 & -21.02 \\
\hline EUMELI MESOTROPHIC & Northern Atlantic & Africa & 18.5 & -21.08 \\
\hline BOFS-1 & Northern Atlantic & Africa & 19 & -20.17 \\
\hline CB1-1 & Northern Atlantic & Africa & 20.92 & -19.75 \\
\hline CB1-2 & Northern Atlantic & Africa & 20.92 & -19.74 \\
\hline CB1-3 & Northern Atlantic & Africa & 20.92 & -19.74 \\
\hline CB2-1 & Northern Atlantic & Africa & 21.15 & -20.68 \\
\hline CB2-2 & Northern Atlantic & Africa & 21.15 & -20.69 \\
\hline EUMELI OLIGOTROPHIC & Northern Atlantic & Africa & 21.15 & -31.17 \\
\hline $22 \mathrm{~N} 25 \mathrm{~W}$ & Northern Atlantic & Africa & 21.93 & -25.23 \\
\hline $25 \mathrm{~N} 23 \mathrm{~W}$ & Northern Atlantic & Africa & 24.55 & -22.83 \\
\hline $28 \mathrm{~N} 22 \mathrm{~W}$ & Northern Atlantic & Africa & 28 & -21.98 \\
\hline CI 1 UPPER & Northern Atlantic & Africa & 29.11 & -15.45 \\
\hline ST & Northern Atlantic & Africa & 31.55 & -24.67 \\
\hline SARGASSO & Northern Atlantic & Africa & 32.08 & -64.25 \\
\hline L1-93 & Northern Atlantic & Africa & 33.15 & -21.98 \\
\hline $34 \mathrm{~N}-21 \mathrm{~W}$ & Northern Atlantic & Africa & 33.82 & -21.02 \\
\hline $48 \mathrm{~N} 21 \mathrm{~W}-1$ & Northern Atlantic & Africa & 47.72 & -20.87 \\
\hline $48 \mathrm{~N} 21 \mathrm{~W}-2$ & Northern Atlantic & Africa & 47.83 & -19.5 \\
\hline
\end{tabular}

is sampled during MAM for comparison. All three distributions in Fig. 9a show roughly similar peaks (2.5 to $3.2 \mu \mathrm{m}$ in diameter) with roughly similar spectral dispersions. In term of emission of small-size dust particles, the sensitivity case is better. The peaks of the three distributions in Fig. $9 \mathrm{~b}$ are around $3.5-5 \mu \mathrm{m}$ in diameter but with very different spectral dispersions. For the clay mass fraction, the base case agrees better with the observation. Contrary to the NAMMA 
(a) Ginoux et al. (2001)

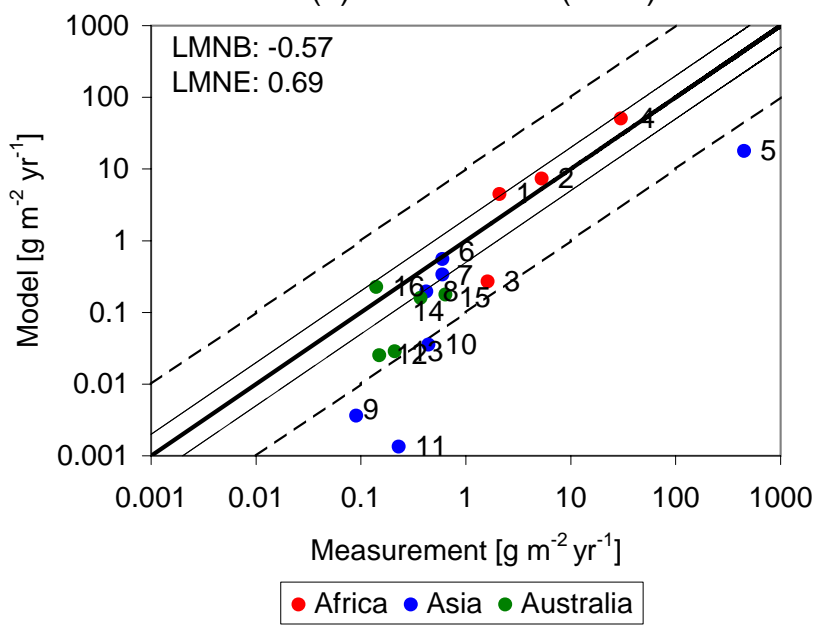

(b) Tegen et al. (2002)

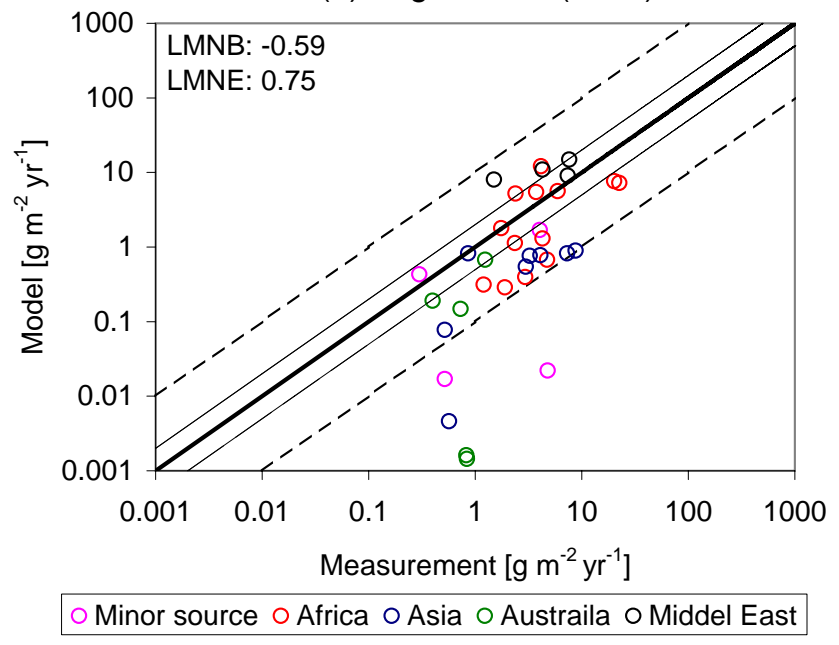

Fig. 8. Scatter plots of monthly averaged deposition fluxes of mineral dust, predicted and observed, in units of $\mathrm{g} \mathrm{m}^{-2} \mathrm{yr}^{-1}$. Deposition flux observed from Ginoux et al. (2001) and Tegen et al. (2002) is shown in (a) and (b), respectively. Log-mean normalized bias (LMNB) and log-mean normalized error (LMNE) are given. Thick and thin solid lines are the 1:1 line and 2:1 lines, respectively. Dashed lines are 10:1 lines. Note the number given at each site corresponds to the site number in Table 4.

comparison, there is a significant overprediction of fine dust particles in the sensitivity simulation. The discrepancy between model and observation could result from the global constant soil mass fraction in the model. According to Grini and Zender (2004), physically based models tend to predict better dust source size distribution compared to observations. Using soil mass fraction, which neglects the dependence of vertical flux on friction velocity, in the dust emission scheme might result in the discrepancy in size distributions between our model and observation. However it is worthwhile to note that different instruments report different peaks in the dust (a) NAMMA

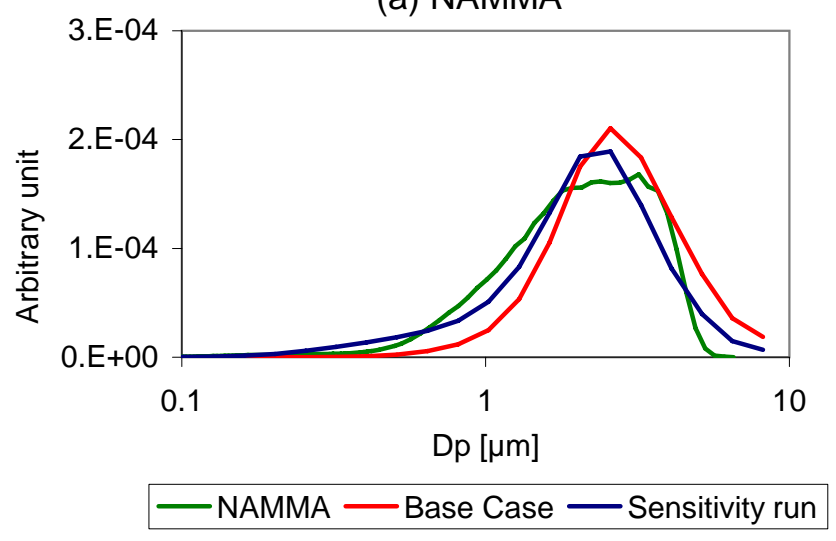

(b) ACE-Asia

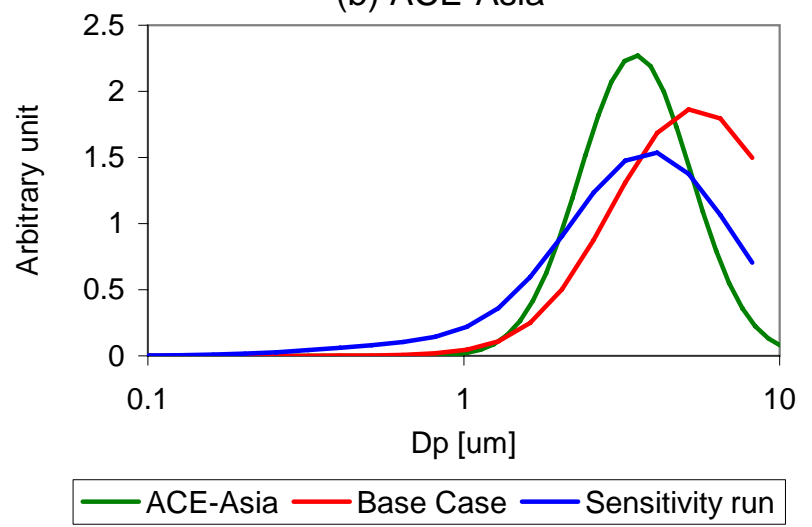

Fig. 9. (a) Mass size distribution from the NAMMA campaign (green) and re-scaled mass size distributions of the model base case (red) and the model sensitivity case (blue) near the African dust source region $\left(20^{\circ} \mathrm{W}\right.$ to $30^{\circ} \mathrm{W}$ longitude and $10^{\circ} \mathrm{N}$ to $20^{\circ} \mathrm{N}$ latitude). (b) Same for mass size distribution from Zhang et al. (2003) (green) and re-scaled emission mass size distribution of the model base case (red) and the model sensitivity case (blue). See text for a more complete discussion of the observational data sets. Note that the total mass of the two model cases is normalized to achieve the same total mass as the field campaign data.

mass size distribution (Reid et al., 2003). The NAMMA campaign uses the Aerodynamic Particle Sizer (APS), and the ACE-Asia uses a cascade impactor. Reid et al. (2003) shows discrepancies in mean diameters of size distributions measured with different impactors as well as with APS. The observed distribution in the NAMMA shows a large and unrealistic drop above $8 \mu \mathrm{m}$ caused by measurement issues, so a meaningful comparison is not possible in this size range.

\subsection{Sensitivity simulation}

Both observational comparisons suggest that modeled dust is underpredicted significantly in remote locations. As discussed in Sect. 3.1, our average particle size is larger than other global models, contributing to a short dust lifetime and 

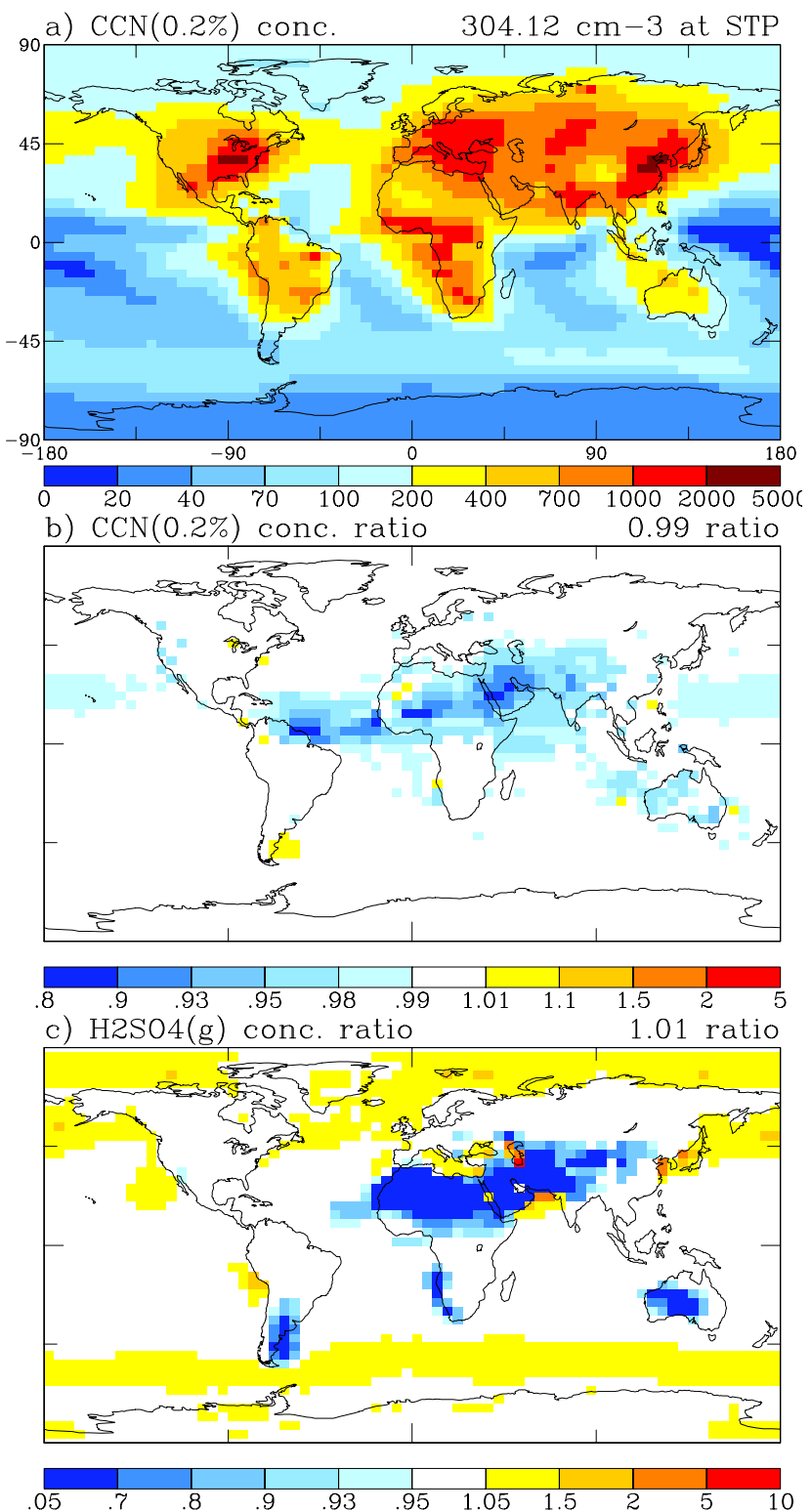

Fig. 10. (a) Annually averaged $\operatorname{CCN}(0.2 \%)$ concentrations in the first vertical layer $\left[\mathrm{cm}^{-3}\right.$ at $273 \mathrm{~K}$ and $1013 \mathrm{hPa}$ ] from the model base case, (b) the ratio of predicted annual-average $\mathrm{CCN}(0.2 \%)$ concentrations including mineral dust to a scenario without mineral dust in the first vertical layer, and (c) same as (b) but for predicted annual average gas-phase $\mathrm{H}_{2} \mathrm{SO}_{4}$ concentrations.

perhaps too little long-range transport. Here, we investigate an alternative formulation of the dry threshold velocity, $u_{t, 0}$, based on Ginoux et al. (2001) to see if dust predictions in remote areas are improved. As presented in Table 1, the dust lifetime in the sensitivity simulation is increased to 3.7 days from 2.6 days. Dust mass concentrations in the sensitivity simulation are slightly improved; the LMNB changes from -0.40 to -0.34 , and the LMNE changes from 0.51 to 0.51 . Deposition fluxes in the sensitivity simulation are not improved unambiguously: for the Ginoux et al. (2001) compilation, LMNB improves slightly to -0.48 from -0.57 but the LMNE worsens slightly to 0.71 from 0.69 ; for the Tegen et al. (2002) compilation, LMNB improves slightly to -0.55 from -0.59 and LMNE to 0.71 from 0.75 . Even with the longer dust lifetime in the sensitivity simulation, the underestimation in the remote regions is not improved. This indicates that the model underestimation in remote locations is perhaps due to underestimation of local emissions (caused by the GCM meteorology or problems in the dust emission parameterization) rather than short lifetime of dust aerosols.

\subsection{Cloud condensation nuclei concentrations}

Figure 10 shows a global distribution of annual-average $\mathrm{CCN}$ (cloud condensation nuclei) concentrations at $0.2 \%$ supersaturation and their percent change in the first vertical layer when dust is included in the model. Over most of the globe, $\mathrm{CCN}(0.2 \%)$ concentrations in a simulation without dust (Pierce et al., 2007) are almost identical to those with dust. However, in dust regions, there are modest decreases of $10 \%$ to $20 \%$ in $\mathrm{CCN}(0.2 \%)$ concentrations. Although dust emissions are a direct source of $\mathrm{CCN}$ in the model (the assumption of internal mixing guarantees that there is always enough soluble material for large dust particles to activate), their number concentrations are small, so the direct impact of dust on $\mathrm{CCN}(0.2 \%)$ is expected to be small. The decrease in $\mathrm{CCN}(0.2 \%)$ could result from two microphysical feedbacks that outweigh the direct contribution of dust. First, $\mathrm{CCN}$ and ultrafine particles growing to become $\mathrm{CCN}$ undergo coagulational scavenging by the larger dust particles. Second, the additional surface area associated with dust particles competes with ultrafine and $\mathrm{CCN}$ particles for condensable $\mathrm{H}_{2} \mathrm{SO}_{4}$. Figure 10c shows the $\mathrm{H}_{2} \mathrm{SO}_{4}$ concentration ratio for the simulations with dust and without dust. A strong reduction in gas-phase $\mathrm{H}_{2} \mathrm{SO}_{4}$ concentration is correlated with the dusty regions, which results in slower condensational growth of ultrafine mode $(10 \mathrm{~nm}$ to $100 \mathrm{~nm})$ particles into the accumulation mode $(0.1 \mu \mathrm{m}$ to $0.5 \mu \mathrm{m})$. The upper boundary of the accumulation mode is selected to be $0.5 \mu \mathrm{m}$ to separate size ranges with and without dust.

Examining column and latitude average $\left(26^{\circ} \mathrm{N}-30^{\circ} \mathrm{N}\right)$ accumulation-mode number concentrations in a dusty region, we see that they decrease from 46.0 to $44.5 \mathrm{~cm}^{-3}$ when dust is added to the model. In the same region, total sources of accumulation mode particles (including direct emission, condensational and coagulational growth from the ultrafine mode, and cloud processing) are reduced by $1.9 \%$ in the scenario with dust. The majority of this reduction $(75 \%)$ is slower condensational growth due to lower $\mathrm{H}_{2} \mathrm{SO}_{4}$ concentrations (see Fig. 10c). Changes in coagulation growth and cloud processing are responsible for the remainder. At the same time, the lifetime of accumulation mode particles in this area decreases from 8.5 to 8.44 days. To separate whether decreased sources or decreased lifetime contributes 

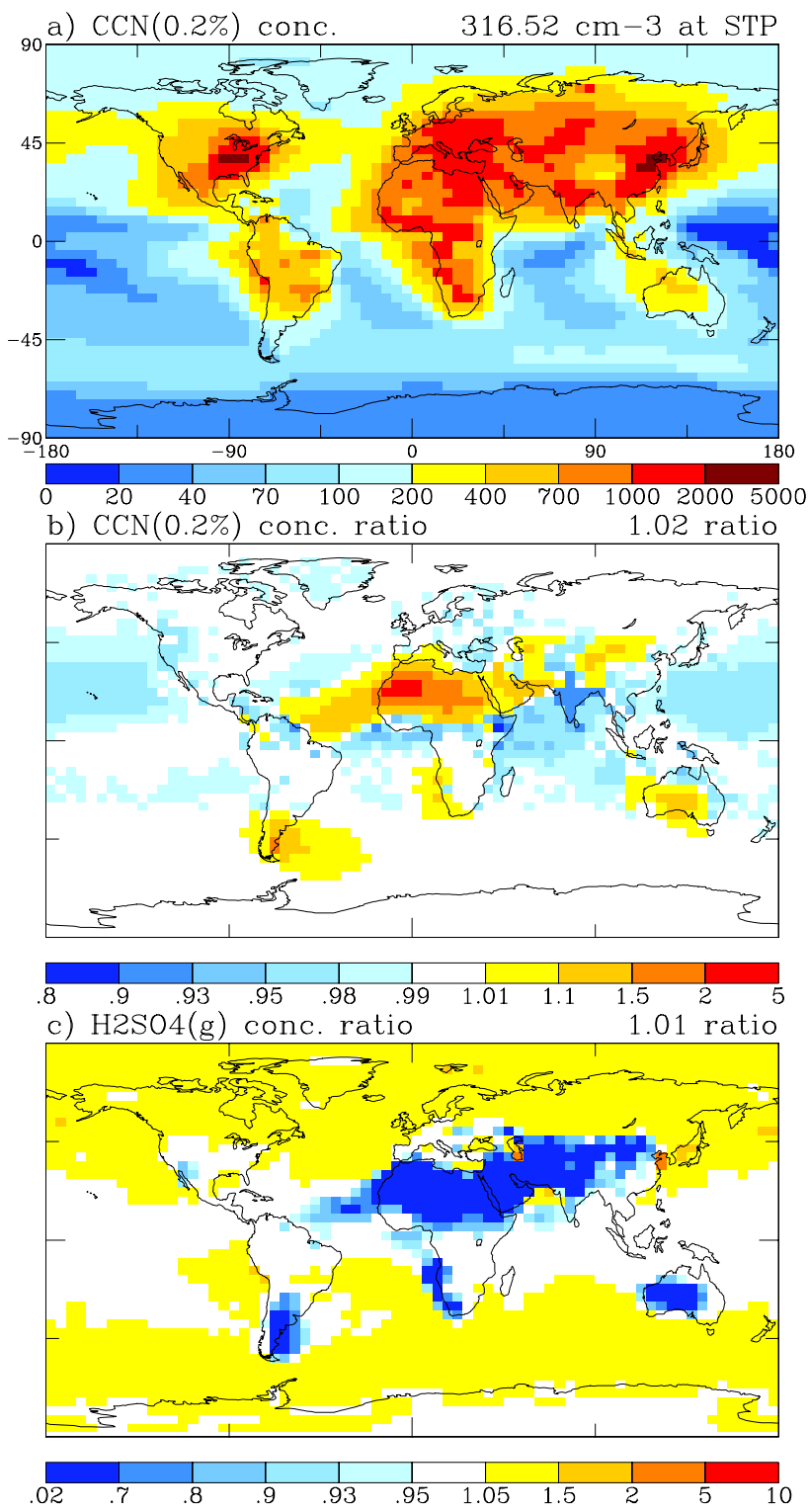

Fig. 11. Same as Figure 10 but for the sensitivity case compared to the case without dust.

more to the decreased number of $\mathrm{CCN}(0.2 \%)$, the following equation is applied (Racherla and Adams, 2006):

$\frac{M_{\text {dust }}-M_{\text {nodust }}}{M_{\text {dust }}}=\frac{S_{\text {dust }}-S_{\text {nodust }}}{S_{\text {dust }}}+\frac{\tau_{\text {dust }}-\tau_{\text {nodust }}}{\tau_{\text {dust }}}$

where $M$ stands for $\mathrm{CCN}(0.2 \%)$ burden (proportional to number concentration), $S$ for total sources, and $\tau$ for lifetime. The "dust" and "nodust" subscripts refer to simulations with and without dust, respectively. The first and second terms on the right-hand side of the equation, represent the effects of changed sources and sinks, respectively. Using Eq. (5), the change in accumulation mode particles in this region is contributed mostly by the source change $(\sim 80 \%)$. Along with

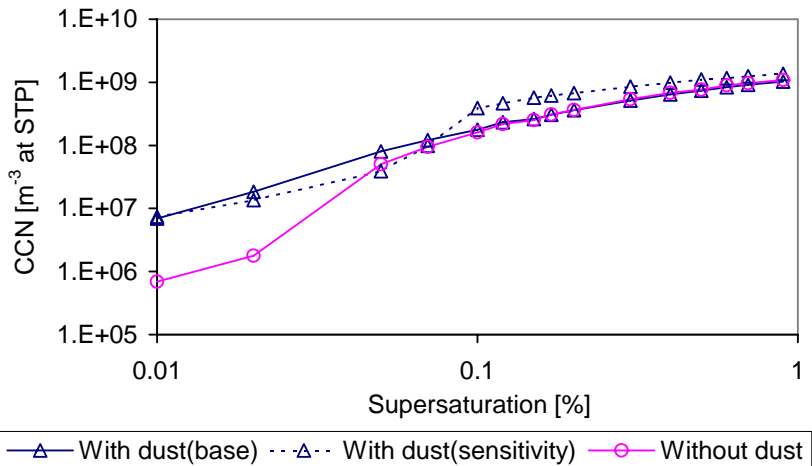

Fig. 12. CCN spectra $\left(\mathrm{m}^{-3}\right.$ at $273 \mathrm{~K}$ and $\left.1013 \mathrm{hPa}\right)$ with and without dust aerosols in the African dust region (18 to $21^{\circ} \mathrm{N}, 7$ to $\left.12^{\circ} \mathrm{W}\right)$. Blue solid and dashed line with triangles are dust model simulation in the base case and the sensitivity case, respectively. The pink solid line with circles is the model simulation without dust.

Fig. 10c, this reflects that the lower $\mathrm{CCN}(0.2 \%)$ concentration in Fig. 10b, is mainly due to lower gas-phase $\mathrm{H}_{2} \mathrm{SO}_{4}$ concentrations and slower condensational growth of ultrafine to $\mathrm{CCN}$ particles in the presence of dust.

Similarly, the number concentration of ultrafine particles is reduced in dusty regions (not shown). The same type of analysis (Eq. 5) shows that the reduction in total ultrafine lifetime (from 1.69 to 1.67 days) is primarily the result of a shorter lifetime with respect to coagulation. We conclude that coagulational scavenging of ultrafine particles by mineral dust is responsible for the reduction.

Analogous figures showing the impact of dust on $\mathrm{CCN}(0.2 \%)$ for the sensitivity case are shown in Fig. 11 . Unlike the base case, in dusty regions, Fig. 11b shows increases in $\mathrm{CCN}(0.2 \%)$ concentrations from $10 \%$ to more than a factor of two. Although the condensational growth of ultrafine particles to $\mathrm{CCN}$ is reduced by the additional dust surface area (see Fig. 11c), the significant mineral dust emissions in the fine mode directly increase $\mathrm{CCN}(0.2 \%)$ concentrations. Noting the opposite effects of mineral dust on $\operatorname{CCN}(0.2 \%)$ concentrations in the base and sensitivity cases, we conclude that the impact of dust on $\mathrm{CCN}(0.2 \%)$ is very sensitive to uncertainties in the dust emission size distribution. Although the dust size distribution in the sensitivity case slightly outperformed the base case in the comparison with the NAMMA campaign, it is difficult to rule out either scenario at the present time.

To investigate the impact of dust on CCN more generally, $\mathrm{CCN}$ spectra are calculated with and without dust aerosol in the African region ( 18 to $21^{\circ} \mathrm{N}, 7$ to $12^{\circ} \mathrm{W}$ ). The $\mathrm{CCN}$ spectra in Fig. 12 show higher $\mathrm{CCN}$ concentrations with dust at lower supersaturation values from $0.01 \%$ to $0.1 \%$. This effect is mostly due to direct emission of dust and is most pronounced at the lowest supersaturations where the addition of easily activated coarse particles is most noticeable. Recall that our model assumes internal mixing and coarse 
dust particles require only small fractions of soluble material to activate. An exception to this behavior is the $\mathrm{CCN}$ concentrations at $0.05 \%$ supersaturation, which are lower in the sensitivity case than in the case without dust. Here, the changing aerosol composition is playing the dominant role; the addition of insoluble dust shifts the activation diameter to larger particle sizes and reduces the $\mathrm{CCN}$ active at this supersaturation. This effect is small, however, and depends on a specific mix and size distributions of soluble species (sulfate, seasalt, hydrophilic organic matter) and mineral dust. At higher supersaturations corresponding to smaller particles, there are two opposite results from with dust in the base and sensitivity cases. The base case shows reduced $\mathrm{CCN}$ by dust due to the lower $\mathrm{H}_{2} \mathrm{SO}_{4}$ concentrations mentioned in previous paragraphs, while the sensitivity case shows increased $\mathrm{CCN}$ by direct emission that compensates number reduction by the lower $\mathrm{H}_{2} \mathrm{SO}_{4}$ concentrations. Along with Figs. 10 and 11, it shows CCN is sensitive to the emission size distributions. This simple analysis suggests but does not directly address potentially important effects of dust on precipitation by acting as giant CCN or ice nuclei (e.g. Levin et al., 2005; Posselt and Lohmann, 2007) or to suppress rainfall (Rosenfeld et al., 2001).

\section{Summary and conclusions}

The dust module developed for the TOMAS global aerosol microphysics model was evaluated against measured surface mass concentrations, deposition fluxes, and size distributions. The evaluation of dust predictions with dust surface mass concentrations and deposition fluxes shows reasonably good prediction in dusty regions (agreement within a factor of 2 for concentrations above $0.5 \mu \mathrm{g} \mathrm{m}^{-3}$; a factor of 3 for deposition fluxes above $0.5 \mathrm{~g} \mathrm{~m}^{-2} \mathrm{yr}^{-1}$ ), sometimes with a modest low bias, but more severe underpredictions in remote regions (agreement within a factor of 3 for concentrations overall and a factor of 5 for deposition fluxes overall) such as near the equator. The dust budget comparison to other global models shows higher emissions but an intermediate burden due to the model's short lifetime. A sensitivity simulation with a different dry threshold velocity, smaller dust particles and a longer lifetime, shows only slightly better representation of size distribution as compared to the observation but nearly no improvement of a model predictions in remote locations. Poor model predictions in remote areas are perhaps due to the GCM meteorology and/or the difficulty of capturing smaller-scale local emissions with a global dust emissions parameterization. A sensitivity case with increased long-range transport did little to improve model predictions in these areas.

Dust particles in the model do not influence $\mathrm{CCN}(0.2 \%)$ concentrations in most parts of the globe but have significant impacts in dust regions. The $\mathrm{CCN}(0.2 \%)$ concentrations in dusty areas decreased up to $20 \%$ in the base case mainly as the result of the additional aerosol surface area provided by dust causing a suppression of $\mathrm{H}_{2} \mathrm{SO}_{4}$ concentrations and less condensational growth of ultrafine particles to $\mathrm{CCN}$ sizes. In the sensitivity case, dust caused increases up to a factor of two in $\mathrm{CCN}(0.2 \%)$ concentrations as the result of significant dust emissions to the fine mode. The effect of dust on $\mathrm{CCN}$ is therefore highly sensitive to uncertainties in the dust emissions size distribution. At low supersaturations (below $0.1 \%$ ), there are generally higher CCN concentrations with dust mostly as the result of direct dust emission into the coarse particle size range. Although this result highlights only one of many effects of mineral dust on clouds and precipitation, the development of the TOMAS dust model lays the basis for more systematic work in the future.

Acknowledgements. This research was supported by NASA Grant No. NNG04GD53G. We thank Joseph M. Prospero and Dennis L. Savoie for providing the measurements of dust mass concentrations and Gao Chen for providing the NAMMA campaign dust size distribution measurements.

Edited by: B. Kärcher

\section{References}

Adams, P. J. and Seinfeld, J. H.: Predicting global aerosol size distributions in general circulation models, J. Geophys. Res.Atmos., 107, 4370, doi:10.1029/2001JD001010, 2002.

Alfaro, S. C. and Gomes, L.: Modeling mineral aerosol production by wind erosion: Emission intensities and aerosol size distributions in source areas, J. Geophys. Res.-Atmos., 106, D16, 18075-18084, 2001.

Arimoto, R., Ray, B. J., Duce, R. A., Hewitt, A. D., Boldi, R., and Hudson, A.: Concentrations, Sources, and Fluxes of TraceElements in the Remote Marine Atmosphere of New-Zealand, J. Geophys. Res.-Atmos., 95, D13, 22389-22405, 1990.

Benkovitz, C. M., Scholtz, M. T., Pacyna, J., Tarrason, L., Dignon, J., Voldner, E. C., Spiro, P. A., Logan, J. A., and Graedel, T. E.: Global gridded inventories of anthropogenic emissions of sulfur and nitrogen, J. Geophys. Res.-Atmos., 101, D22, 29239-29253, 1996.

Bond, T. C., Streets, D. G., Yarber, K. F., Nelson, S. M., Woo, J. H., and Klimont, Z.: A technology-based global inventory of black and organic carbon emissions from combustion, J. Geophys. Res.-Atmos., 109, D14203, doi:10.1029/2003JD003697, 2004.

Cakmur, R. V., Miller, R. L., and Torres, O.: Incorporating the effect of small-scale circulations upon dust emission in an atmospheric general circulation model, J. Geophys. Res.-Atmos., 109, D07201, doi:10.1029/2003JD004067, 2004.

Carlson, T. N. and Prospero, J. M.: Large-Scale Movement of Saharan Air Impulses over Western Tropical Atlantic, B. Am. Meteorol. Soc., 52, 8, 779-792, 1971.

Chiapello, I., Bergametti, G., Gomes, L., Chatenet, B., Dulac, F., Pimenta, J., and Suares, E. S.: An Additional Low Layer Transport of Sahelian and Saharan Dust over the North-Eastern Tropical Atlantic, Geophys. Res. Lett., 22, 23, 3191-3194, 1995. 
Chiapello, I., Prospero, J. M., Herman, J. R., and Hsu, N. C.: Detection of mineral dust over the North Atlantic Ocean and Africa with the Nimbus 7 TOMS, J. Geophys. Res.-Atmos., 104, D8, 9277-9291, 1999.

Clarke, A. D., Owens, S. R. and Zhou, J. C.: An ultrafine seasalt flux from breaking waves: Implications for cloud condensation nuclei in the remote marine atmosphere, J. Geophys. Res.Atmos., 111, D06202, doi:10.1029/2005JD006565, 2006.

Dalmeida, G. A. and Schutz, L.: Number, Mass and Volume Distributions of Mineral Aerosol and Soils of the Sahara, J. Clim. Appl. Meteorol., 22, 2, 233-243, 1983.

Del Genio, A. D. and Yao, M.-S.: Efficient cumulus parameterization for long-term climate studies: The GISS scheme, in: The Representation of Cumulus Convection in Numerical Models, AMS Monogr. Ser., edited by: Emanuel, K. A. and Raymond, D. J., Am. Meteorol. Soc., Boston, Mass., 181-184, 1993.

Del Genio, A. D., Yao, M. S., Kovari, W., and Lo, K. K. W.: A prognostic cloud water parameterization for global climate models, J. Climate, 9(2), 270-304, 1996.

Dentener, F. J., Carmichael, G. R., Zhang, Y., Lelieveld, J., and Crutzen, P. J.: Role of mineral aerosol as a reactive surface in the global troposphere, J. Geophys. Res.-Atmos., 101, D17, 2286922889, 1996.

Dick, A. L.: Concentrations and Sources of Metals in the Antarctic Peninsula Aerosol, Geochim. Cosmochim. Ac., 55, 7, $1827-$ 1836, 1991.

Gasso, S. and Stein, A. F.: Does dust from Patagonia reach the sub-Antarctic Atlantic ocean?, Geophys. Res. Lett., 34, L01801, doi:10.1029/2006GL027693, 2007.

Gillette, D. A. and Passi, R.: Modeling Dust Emission Caused by Wind Erosion, J. Geophys Res.-Atmos., 93, D11, 14233-14242, 1988.

Ginoux, P., Chin, M., Tegen, I., Prospero, J. M., Holben, B., Dubovik, O., and Lin, S. J.: Sources and distributions of dust aerosols simulated with the GOCART model, J. Geophys. Res.Atmos., 106, D17, 20255-20273, 2001.

Ginoux, P., Prospero, J. M., Torres, O., and Chin, M.: Longterm simulation of global dust distribution with the GOCART model: correlation with North Atlantic Oscillation, Environ. Modell Softw, 19(2), 113-128, 2004.

Gong, S. L., Zhang, X. Y., Zhao, T. L., McKendry, I. G., Jaffe, D. A., and Lu, N. M.: Characterization of soil dust aerosol in China and its transport and distribution during 2001 ACE-Asia: 2. Model simulation and validation, J Geophys. Res.-Atmos., 108(D9), doi:10.1029/2002JD002633, 2003.

Goudie, A. S. and Middleton, N. J.: Saharan dust storms: nature and consequences, Earth-Sci. Rev., 56(1-4), 179-204, 2001.

Griffin, D. W., Kellogg, C. A., Garrison, V. H., and Shinn, E. A.: The global transport of dust - An intercontinental river of dust, microorganisms and toxic chemicals flows through the Earth's atmosphere, Am, Sci, 90(5), 398-398, 2002.

Griffin, D. W., Westphal, D. L., and Gray, M. A.: Airborne microorganisms in the African desert dust corridor over the mid-Atlantic ridge, Ocean Drilling Program, Leg 209, Aerobiologia, 22(3), 211-226, 2006.

Grini, A. and Zender, C. S.: Roles of saltation, sandblasting, and wind speed variability on mineral dust aerosol size distribution during the Puerto Rican Dust Experiment (PRIDE), J. Geophys. Res.-Atmos., 109, D07202, doi:10.1029/2003JD004233, 2004.
Hansen, J., Russell, G., Rind, D., Stone, P., Lacis, A., Lebedeff, S., Ruedy, R., and Travis, L.: Efficient 3-Dimensional Global-Models for Climate Studies - Model-I and Model-Ii, Mon. Weather Rev., 111, 4, 609-662, 1983.

Hartke, G. J. and Rind, D.: Improved surface and boundary layer models for the Goddard Institute for Space Studies general circulation model, J. Geophys. Res.-Atmos., 102, D14, 16407-16422, 1997.

Jickells, T. D., An, Z. S., Andersen, K. K., Baker, A. R., Bergametti, G., Brooks, N., Cao, J. J., Boyd, P. W., Duce, R. A., Hunter, K. A., Kawahata, H., Kubilay, N., laRoche, J., Liss, P. S., Mahowald, N., Prospero, J. M., Ridgwell, A. J., Tegen, I., and Torres, R.: Global iron connections between desert dust, ocean biogeochemistry, and climate, Science, 308, 5718, 67-71, 2005.

Koch, D., Jacob, D., Tegen, I., Rind, D., and Chin, M.: Tropospheric sulfur simulation and sulfate direct radiative forcing in the Goddard Institute for Space Studies general circulation model, J. Geophys. Res.-Atmos., 104(D19), 23799-23822, 1999.

Levin, Z., Teller, A., Ganor, E., and Yin, Y.: On the interactions of mineral dust, sea-salt particles, and clouds: A measurement and modeling study from the Mediterranean Israeli Dust Experiment campaign, J. Geophys. Res.-Atmos., 110, D20202, doi:10.1029/2005JD005810, 2005.

Mahowald, N., Kohfeld, K., Hansson, M., Balkanski, Y., Harrison, S. P., Prentice, I. C., Schulz, M., and Rodhe, H.: Dust sources and deposition during the last glacial maximum and current climate: A comparison of model results with paleodata from ice cores and marine sediments, J. Geophys. Res.-Atmos., 104(D13), 1589515916, 1999.

Mahowald, N. M. and Kiehl, L. M.: Mineral aerosol and cloud interactions, Geophys. Res. Lett., 30, 1475, doi:10.1029/2002GL016762, 2003.

Mahowald, N. M. and Luo, C.: A less dusty future?, Geophys. Res. Lett., 30, 1903, doi:10.1029/2003GL017880, 2003.

Mahowald, N. M., Baker, A. R., Bergametti, G., Brooks, N., Duce, R. A., Jickells, T. D., Kubilay, N., Prospero, J. M., and Tegen, I.: Atmospheric global dust cycle and iron inputs to the ocean, Global Biogeochem. Cy., 19, GB4025, doi:10.1029/2004GB002402, 2005.

Marticorena, B. and Bergametti, G.: Modeling the Atmospheric Dust Cycle .1. Design of a Soil-Derived Dust Emission Scheme, J. Geophys. Res.-Atmos., 100(D8), 16415-16430, 1995.

Merrill, J. T., Uematsu, M., and Bleck, R.: Meteorological Analysis of Long-Range Transport of Mineral Aerosols over the North Pacific, J. Geophys. Res.-Atmos., 94(D6), 8584-8598, 1989.

Meskhidze, N., Nenes, A., Chameides, W. L., Luo, C., and Mahowald, N.: Atlantic Southern Ocean productivity: Fertilization from above or below?, Global Biogeochem. Cy., 21, GB2006, doi:10.1029/2006GB002711, 2007.

Miller, R. L., Cakmur, R. V., Perlwitz, J., Geogdzhayev, I. V., Ginoux, P., Koch, D., Kohfeld, K. E., Prigent, C., Ruedy, R., Schmidt, G. A., and Tegen, I.: Mineral dust aerosols in the NASA goddard institute for Space Sciences ModelE atmospheric general circulation model, J. Geophys. Res.-Atmos., 111, D06208, doi:10.1029/2005JD005796, 2006.

Pierce, J. R. and Adams, P. J.: Global evaluation of $\mathrm{CCN}$ formation by direct emission of sea salt and growth of ultrafine sea salt, J. Geophys. Res.-Atmos., 111, D06203, 
doi:10.1029/2005JD006186, 2006.

Posselt, R. and Lohmann, U.: Influence of giant $\mathrm{CCN}$ on warm rain processes in the ECHAM5 GCM, Atmos. Chem. Phys., 8, 14, 3769-3788, 2008.

Prather, M. J.: Numerical Advection by Conservation of 2nd-Order Moments, J Geophys. Res.-Atmos., 91(D6), 6671-6681, 1986.

Prospero, J. M. and Bonatti, E.: Continental Dust in Atmosphere of Eastern Equatorial Pacific, J. Geophys. Res., 74(13), 3362-3371, 1969.

Prospero, J. M., Ginoux, P., Torres, O., Nicholson, S. E., and Gill, T. E.: Environmental characterization of global sources of atmospheric soil dust identified with the Nimbus 7 Total Ozone Mapping Spectrometer (TOMS) absorbing aerosol product, Rev. Geophys., 40, 1002, doi:10.1029/2000RG000095, 2002.

Racherla, P. N. and Adams, P. J.: Sensitivity of global tropospheric ozone and fine particulate matter concentrations to climate change, J. Geophys. Res.-Atmos., 111(D24), doi:10.1029/2005JD006939, 2006.

Reddy, M. S., Boucher, O., Bellouin, N., Schulz, M., Balkanski, Y., Dufresne, J. L., and Pham, M.: Estimates of global multicomponent aerosol optical depth and direct radiative perturbation in the Laboratoire de Meteorologie Dynamique general circulation model, J. Geophys. Res.-Atmos., 110, D10S16, doi:10.1029/2004JD004757, 2005.

Reid, J. S., Jonsson, H. H., Maring, H. B., Smirnov, A., Savoie, D. L., Cliff, S. S., Reid, E. A., Livingston, J. M., Meier, M. M., Dubovik, O., and Tsay, S. C.: Comparison of size and morphological measurements of coarse mode dust particles from Africa, J. Geophys. Res.-Atmos., 108(D19), doi:10.1029/2002JD002485, 2003.

Rosenfeld, D., Rudich, Y., and Lahav, R.: Desert dust suppressing precipitation: A possible desertification feedback loop, P. Natl. Acad. Sci. USA, 98(11), 5975-5980, 2001.

Rosenzweig, C. and Abramopoulos, F.: Land-surface model development for the GISS GCM, J. Climate, 10(8), 2040-2054, 1997.

Sassen, K., DeMott, P. J., Prospero, J. M., and Poellot, M. R.: Saharan dust storms and indirect aerosol effects on clouds: CRYSTAL-FACE results, Geophys. Res. Lett., 30, 1633, doi:10.1029/2003GL017371, 2003.

Savoie, D. L. and Prospero, J. M.: Comparison of Oceanic and Continental Sources of Non-Sea-Salt Sulfate over the Pacific-Ocean, Nature, 339, 6227, 685-687, 1989.

Shinn, E. A., Smith, G. W., Prospero, J. M., Betzer, P., Hayes, M. L., Garrison, V., and Barber, R. T.: African dust and the demise of Caribbean coral reefs, Geophys. Res. Lett., 27(19), 3029-3032, 2000.
Seinfeld, J. H. and Pandis, S. N.: Atmospheric Chemistry and Physics, John Wiley and Sons, New York, USA, 1998.

Sokolik, I. N., Winker, D. M., Bergametti, G., Gillette, D. A., Carmichael, G., Kaufman, Y. J., Gomes, L., Schuetz, L., and Penner, J. E.: Introduction to special section: Outstanding problems in quantifying the radiative impacts of mineral dust, J. Geophys. Res.-Atmos., 106(D16), 18015-18027, 2001.

Stier, P., Feichter, J., Kinne, S., Kloster, S., Vignati, E., Wilson, J., Ganzeveld, L., Tegen, I., Werner, M., Balkanski, Y., Schulz, M., Boucher, O., Minikin, A., and Petzold, A.: The aerosolclimate model ECHAM5-HAM, Atmos. Chem. Phys., 5, 11251156, 2005, http://www.atmos-chem-phys.net/5/1125/2005/.

Tegen, I. and Fung, I.: Modeling of Mineral Dust in the Atmosphere - Sources, Transport, and Optical-Thickness, J Geophys Res-Atmos, 99, D11, 22897-22914, 1994.

Tegen, I. and Lacis, A. A.: Modeling of particle size distribution and its influence on the radiative sproperties of mineral dust aerosol, J. Geophys. Res.-Atmos., 101(D14), 19237-19244, 1996.

Tegen, I., Harrison, S. P., Kohfeld, K. E., Engelstaedter, S., and Werner, M.: Emission of soil dust aerosol: Anthropogenic contribution and future changes, Geochim. Cosmochim. Ac., 66(15A), A766-A766, 2002.

Uematsu, M., Duce, R. A., Prospero, J. M., Chen, L., Merrill, J. T., and Mcdonald, R. L.: Transport of Mineral Aerosol from Asia over the North Pacific-Ocean, J. Geophys. Res.-Ocan. Atmos, 88(NC9), 5343-5352, 1983.

Uematsu, M., Duce, R. A., and Prospero, J. M.: Deposition of Atmospheric Mineral Particles in the North Pacific-Ocean, J. Atmos. Chem., 3(1), 123-138, 1985.

Umann, B., Arnold, F., Schaal, C., Hanke, M., Uecker, J., Aufmhoff, H., Balkanski, Y., and Van Dingenen, R.: Interaction of mineral dust with gas phase nitric acid and sulfur dioxide during the MINATROC II field campaign: First estimate of the uptake coefficient gamma(HNO3) from atmospheric data, J. Geophys. Res.-Atmos., 110, D22306, doi:10.1029/2005JD005906, 2005.

Zender, C. S., Bian, H. S., and Newman, D.: Mineral Dust Entrainment and Deposition (DEAD) model: Description and 1990s dust climatology, J. Geophys. Res.-Atmos., 108, 4416, doi:10.1029/2002JD002775, 2003.

Zhang, X. Y., Gong, S. L., Shen, Z. X., Mei, F. M., Xi, X. X., Liu, L. C., Zhou, Z. J., Wang, D., Wang, Y. Q., and Cheng, Y.: Characterization of soil dust aerosol in China and its transport and distribution during 2001 ACE-Asia: 1. Network observations, J. Geophys. Res.-Atmos., 108, D9, doi:10.1029/2002JD002632, 2003. 